Chris L. Waring, Stuart I. Hankin, Stephen B. Solomon, Stephen Long, Andrew Yule, Robert Blackley, Sylvester Werczynski, and Andrew C. Baker. Cave radon exposure, dose, dynamics and mitigation. Journal of Cave and Karst Studies, v. 83, no. 1, p. 1-19. DOI:10.4311/2019ES0124

\title{
CAVE RADON EXPOSURE, DOSE, DYNAMICS AND MITIGATION
}

\author{
Chris L. Waring ${ }^{1,}$ C, Stuart I. Hankin'1, Stephen B. Solomon², Stephen Long², Andrew Yule², Robert \\ Blackley ${ }^{1}$, Sylvester Werczynski ${ }^{1}$, and Andrew C. Baker ${ }^{3}$
}

\begin{abstract}
Many caves around the world have very high concentrations of naturally occurring ${ }^{222} \mathrm{Rn}$ that may vary dramatically with seasonal and diurnal patterns. For most caves with a variable seasonal or diurnal pattern, ${ }^{222} \mathrm{Rn}$ concentration is driven by bi-directional convective ventilation, which responds to external temperature contrast with cave temperature. Cavers and cave workers exposed to high ${ }^{222} \mathrm{Rn}$ have an increased risk of contracting lung cancer. The International Commission on Radiological Protection (ICRP) has re-evaluated its estimates of lung cancer risk from inhalation of radon progeny (ICRP 115) and for cave workers the risk may now (ICRP 137) be 4-6 times higher than previously recognized. Cave Guides working underground in caves with annual average ${ }^{222} \mathrm{Rn}$ activity $>1,000 \mathrm{~Bq} \mathrm{~m}^{-3}$ and default ICRP assumptions (2,000 workplace hours per year, equilibrium factor $F=0.4$, dose conversion factor DCF $=14 \mu S v$ $(\mathrm{kBq} \mathrm{h} \mathrm{m})^{-1}$ could now receive a dose of $>20 \mathrm{mSv} \mathrm{y}^{-1}$. Using multiple gas tracers $\left(\delta^{13} \mathrm{C}-\mathrm{CO}_{2}, \mathrm{Rn}\right.$ and $\left.\mathrm{N}_{2} \mathrm{O}\right)$, linked weather, source gas flux chambers, and convective air flow measurements a previous study unequivocally identified the external soil above Chifley Cave as the source of cave ${ }^{222} \mathrm{Rn}$. If the source of ${ }^{222} \mathrm{Rn}$ is external to the cave, a strategy to lower cave ${ }^{222} \mathrm{Rn}$ by passively decreasing summer pattern convective ventilation, which draws ${ }^{222} \mathrm{Rn}$ into caves, is possible without harming the cave environment. A small net annual average temperature difference (warmer cave air) due to geothermal heat flux produces a large net annual volumetric air flow bias (2-5:1) favoring a winter ventilation pattern that flushes Rn from caves with ambient air. Rapid anthropogenic climate change over decades may heat the average annual external temperature relative to the cave temperature that is stabilized by the thermal inertia of the large rock mass. Relative external temperature increases due to climate change (Jenolan Caves, $2008-2018,0.17^{\circ} \mathrm{C}$ ) reduces the winter pattern air flow bias and increases Rn concentration in caves.
\end{abstract}

\section{INTRODUCTION}

${ }^{222} \mathrm{Rn}$ is an inert radioactive gas with a half-life of 3.8 days formed from ${ }^{226} \mathrm{Ra}$ as part of the ${ }^{238} \mathrm{U}$ decay series. ${ }^{220} \mathrm{Rn}$ formed from ${ }^{232}$ Th decay may be measurable in trace concentrations in caves without adding significantly to total radon concentration. Further reference to radon in this paper refers to the more abundant isotope ${ }^{222} \mathrm{Rn}$.

Many of the early cave Rn studies reported high, but variable, Rn concentration, with most expressing a strong seasonal and possible diurnal variation patterns (Gunn et al., 1991; Hakl et al., 1997; Hyland and Gunn, 1994; Middleton et al., 1991; Solomon et al., 1996; Szerbin, 1996). In the absence of further environmental data, the seasonal pattern with high $\mathrm{Rn}$ in summer was often assumed to be due to greater winter air flow diluting underground Rn accumulation (Tanahara et al., 1997; Tremaine et al., 2011). Studies using continuous Rn monitoring in conjunction with environmental monitoring provided greater time resolution to the seasonal patterns, with the addition of caves with the reverse seasonal pattern (Lario et al., 2005) or no annual variation. The divergence in cave Rn patterns appeared to be associated with different cave configurations and consequent ventilation patterns leading to cave classification based on 3D configuration influencing ventilation. Addition of gas tracers such as $\mathrm{CO}_{2}$ that may closely correlate with $\mathrm{Rn}$ activity (Gregoric et al., 2013; Kowalczk and Froelich, 2010), and detailed cave temperature measurements also helped constrain the conceptual model of Rn in caves. However, for many studies, measurement of air flow through the cave is absent and the source of $\mathrm{Rn}$ in caves remains unresolved. To explain fully $\mathrm{Rn}$ dynamics in caves, a challenge remains to classify correctly the 3D void shape and dimensions, consequent ventilation regime and Rn source for the many complex cave variants. In this paper, we describe a typical chimney effect ventilated cave at Jenolan Caves, Australia and what are the causes that affect Rn activity in Chifley Cave (Waring et al., 2017). We also infer mechanisms to explain other cave Rn patterns from selected well described examples.

A cave worker may be exposed to elevated radon concentrations while working underground. The average of the variable radon concentration while working underground is expressed in units $\mathrm{Bq} \mathrm{m}^{-3}$ (Becquerels per cubic metre) and is multiplied by the total time spent underground to estimate cumulative radon exposure, expressed as $\mathrm{Bq} \mathrm{h} \mathrm{m}^{-3}$ (Equation (1)). The International Commission on Radiological Protection (ICRP) advises (ICRP, 2019a) calculating the effective dose from inhaling radon involves multiplying the average radon level by the time exposed (Rn exposure) and by the dose coefficient (Equation (2)). Radon level may also be expressed as a radon activity or concentration.

\footnotetext{
${ }^{1}$ Australian Nuclear Science and Technology Organisation, Environmental Research, Sydney NSW 2234, Australia.

${ }^{2}$ Australian Radiation Protection and Nuclear Safety Agency, Melbourne VIC 3095, Australia

${ }^{3}$ National Parks and Wildlife Service, Bathurst, NSW 2795, Australia

cCorresponding author: clw@ansto.gov.au, chris.waring2@gmail.com
} 
The dose coefficient may be expressed as the dose conversion factor (DCF) in units $\mu$ Sv per $\mathrm{kBq} \mathrm{h} \mathrm{m}^{-3}$ for simple calculation of dose, incorporating assumptions of a default equilibrium factor $F=0.4$. The recommended dose limit for occupationally exposed workers is $20 \mathrm{mSv} \mathrm{y}^{-1}$, averaged over a defined period of 5 years, with no single year exceeding $50 \mathrm{mSv}$ (ICRP, 2007). For cave visitors and the general public, the dose limit is $1 \mathrm{mSv} \mathrm{y}^{-1}$ (ICRP, 2007).

A comprehensive review of the health risk to cavers and cave workers (Field, 2007) is based on the known radiological health risk in 2007, ICRP 65 (ICRP, 1993; UNSCEAR, 2000) and dose estimates using the model software Lungdose 90 (Nikezic and $\mathrm{Yu}, 2001)$. The dose estimates for professional cavers $\left(600 \mathrm{~h} \mathrm{y}^{-1}\right)$ and full-time cave workers with an assumed time in caves of $2,000 \mathrm{~h} \mathrm{y}^{-1}$ is calculated based on a dose conversion factor (DCF) of $12.92 \mu \mathrm{Sv}$ $\left(\mathrm{kBq} \mathrm{h} \mathrm{m}^{-3}\right)^{-1}$ or $20.75 \mathrm{mSv}$ per WLM (Table 7, Field, 2007). This dose conversion factor is similar to the DCF (15 $\mu$ Sv $(\mathrm{kBq} \mathrm{h} \mathrm{m})^{-3}$ tabulated in ICRP 137 for physically active cave workers, assumed to spend $2 / 3$ time in exercise and the recommended more general DCF of $14 \mu \mathrm{Sv}\left(\mathrm{kBq} \mathrm{h} \mathrm{m}^{-3}\right)^{-1}$ for physically active indoor and cave workers in (ICRP, 2017).

Many cave managers will need to consider different strategies for mitigating cave worker exposure to high Rn concentrations in caves. We consider the merits and detriments for approaches based on limiting the time exposure of cave workers, passive modifications to cave ventilation and technologies available to reduce cave Rn concentration.

\section{RADON EXPOSURE AND HEALTH EFFECTS}

When radon gas undergoes radioactive decay, a series of radioactive elements, called radon decay products (RDP), are produced. Some of these RDPs have very short half-lives, and therefore, a significant probability of undergoing radioactive decay during their time in the lung. The energy deposited by the alpha-radiation emitted during these decays can damage cells, leading to an increased risk of lung cancer.

The ICRP has estimated that the cumulative risk of lung cancer up to 75 years of age for lifelong non-smokers is $0.4 \%, 0.5 \%$ and $0.7 \%$ radon activity of 0 (no radon exposure), 100 and $400 \mathrm{~Bq} \mathrm{~m}^{-3}$, respectively (ICRP, 2010). It should be noted that the baseline risk of lung cancer for lifelong cigarette smokers is about 25 times that for non-smokers. Consequently, the corresponding cumulative risk for lifelong smokers is $10 \%, 12 \%$ and $15 \%$ radon activity.

The ICRP uses Effective Dose, usually measured in $\mathrm{mSv}$, as a radiation protection quantity. The main uses of effective dose are the prospective dose assessment for planning and optimization in radiological protection, and demonstration of compliance with dose limits for regulatory purposes. The ICRP has evaluated the probability of the occurrence of a stochastic effect, such as cancer, after exposure to radiation at low dose rates of $4.2 \times 10^{-5}$ per mSv for workers and $5.7 \times 10^{-5}$ per $\mathrm{mSv}$ for the general public (ICRP, 1991). To calculate the effective dose due to exposure to radon, several key quantities must be known or estimated.

The airborne concentration of RDPs is usually quantified in terms of potential alpha energy concentration (PAEC), measured in units, $\mathrm{J} \mathrm{m}^{-3}$. The PAEC of RDPs in complete equilibrium with radon is $5.4 \times 10^{-9} \mathrm{~J} \mathrm{~Bq}^{-1}$. However, radon and its progeny are rarely in equilibrium because the RDPs readily plate out onto the surrounding surfaces, removing them from the atmosphere. The ratio between the actual PAEC and the equilibrium equivalent value is known as the equilibrium factor. Equilibrium factors from 33 caves (Cigna, 2005) show a wide variation from 0.19 to 0.94 . The measurement weighted average equilibrium factor is $F=0.57, n=880$ (Table 6, Cigna, 2005). The Jenolan Caves equilibrium factor $F=0.55$ (Zahorowski et al., 1998) is very close to the global average (Cigna, 2005).

Exposure to RDPs is measured in terms of the product of PAEC, the breathing rate and the duration of the exposure. While the SI unit for RDP exposure is $\mathrm{J} \mathrm{h} \mathrm{m}^{-3}$, an historical unit still used in some countries is the Working Level Month, where $1 \mathrm{WLM}=3.54 \mathrm{~mJ} \mathrm{~h} \mathrm{~m}^{-3}$. The unit of Working Level, popular in the U.S., is derived from mine literature for Rn exposure. $1 \mathrm{WL}=101.3 \mathrm{pCi} \mathrm{L}^{-1}$ or $3,746 \mathrm{~Bq} \mathrm{~m}^{-3}$ of ${ }^{222} \mathrm{Rn}$ in equilibrium with its short-lived decay products.

\section{Historic ICRP Guidelines and Reference Levels}

In 1993, the ICRP recommended that dosimetric models should not be used for the assessment and control of radon exposure (ICRP, 1993). At that time, the ICRP concluded that the epidemiology of radon in mines was a more appropriate indicator of detriment than the more uncertain dosimetric models. The epidemiology led to the so-called conversion conventions wherein the recommended dose conversion factors (DCFs) were $1.43 \mathrm{mSv}\left(\mathrm{mJ} \mathrm{h} \mathrm{m}^{-3}\right)^{-1}$ for workers and $1.1 \mathrm{mSv}\left(\mathrm{mJ} \mathrm{h} \mathrm{m}^{-3}\right)^{-1}$ for members of the public. Using the standard value of 0.4 for the equilibrium factor yields a DCF in terms of radon concentration of $3.1 \mu \mathrm{Sv}\left(\mathrm{kBq} \mathrm{h} \mathrm{m}^{-3}\right)^{-1}$ for workers (Table 1). If instead, the equilibrium factor for the average cave $(F=0.57)$ developed by Cigna (2005) or the average for Jenolan Caves $(F=0.55)$ Zahorowski et al. (1998) is used, the DCF is $4.4 \mu \mathrm{Sv}\left(\mathrm{kBq} \mathrm{h} \mathrm{m}^{-3}\right)^{-1}$ or $4.2 \mu \mathrm{Sv}\left(\mathrm{kBq} \mathrm{h} \mathrm{m}^{-3}\right)^{-1}$, respectively.

Based on these DCFs, the ICRP recommended that remedial measures should be instituted or its system of radiological protection adopted where radon concentration in workplaces exceeds an action level between 500 and 1,500 $\mathrm{Bq} \mathrm{m}^{-3}$. 
Waring, Hankin, Solomon, Long, Yule, Blackley, Werczynski, and Baker

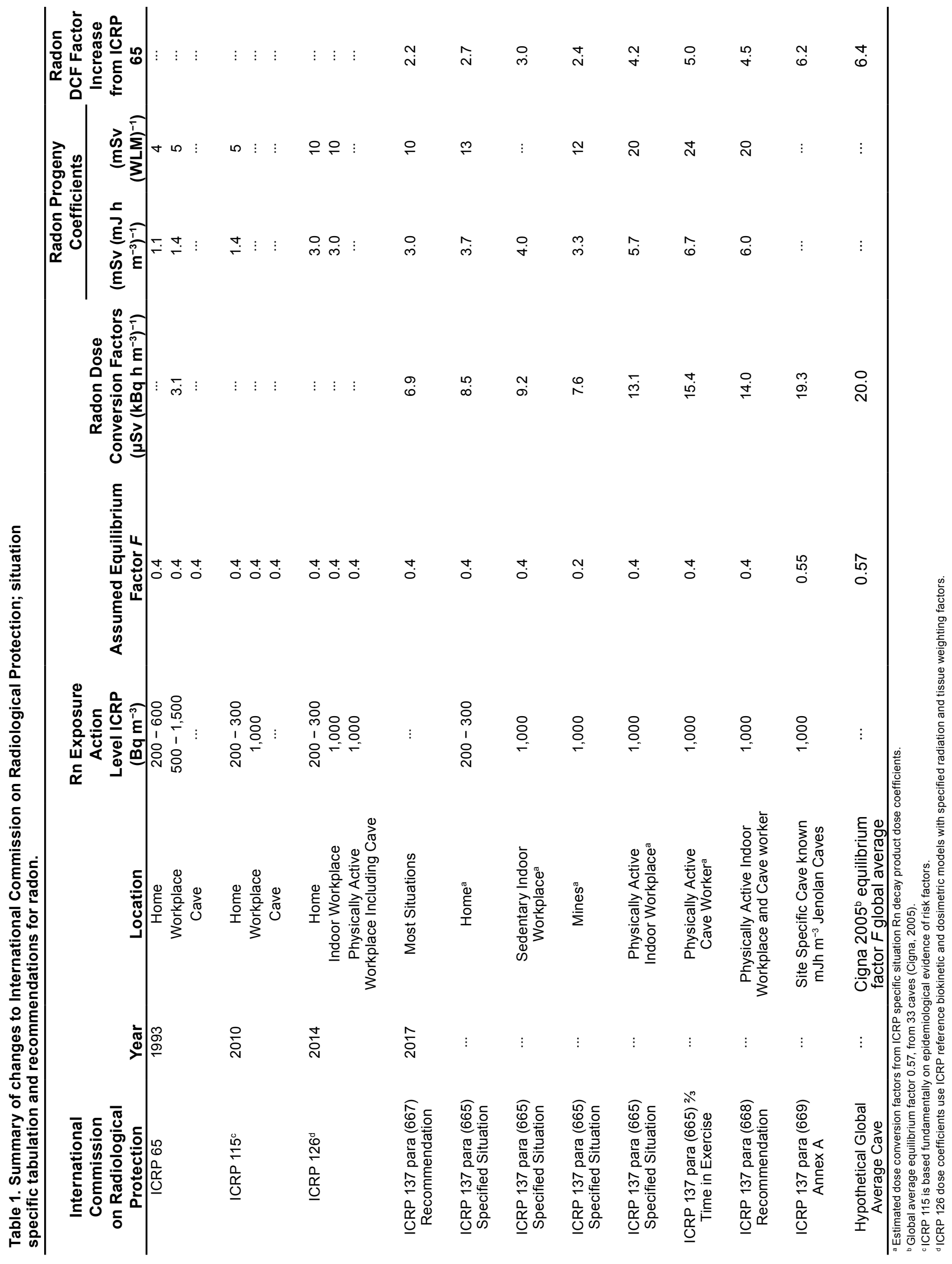




\section{Other Dose Conversion Factors}

Prior to adopting the conversion convention, the ICRP had recommended (ICRP, 1987) a DCF of $10 \mu \mathrm{Sv}(\mathrm{kBq} h$ $\left.\mathrm{m}^{-3}\right)^{-1}$ equilibrium equivalent radon concentration, based on a dosimetric model. Using the conversion factors given in ICRP Publication 50, this DCF is equal to $1.8 \mathrm{mSv}\left(\mathrm{mJ} \mathrm{h} \mathrm{m}^{-3}\right)^{-1}$.

The United Nations Committee on the Effects of Atomic Radiation (UNSCEAR) calculated a DCF of $1.6 \mathrm{mSv}$ $\left(\mathrm{mJ} \mathrm{h} \mathrm{m}^{-3}\right)^{-1}$, also based on a dosimetric model (UNSCEAR, 1982). In its 2000 report, UNSCEAR recognized that more recent calculations with new dosimetric models resulted in higher values of dose conversion factor. However, UNSCEAR concluded that its calculated value was well within the range of possible dose conversion factors, and therefore, should continue to be used in dose evaluations (UNSCEAR, 2000, 2009). An equation in UNSCEAR (Annex B: p107, 2000) explicitly states the applied equilibrium factor separately from the dose conversion factor. For the equivalent equation, the ICRP incorporates the default equilibrium factor $(F=0.4)$ into published dose conversion factors, omitting explicit equilibrium factors to calculate dose from Rn exposure (ICRP, 2019a).

Field (2007) applied a dosimetric model from Nikezic and Yu (2001) to calculate doses to workers in caves. This model was based on the respiratory system model in ICRP Publication 66, "Human Respiratory Tract Model for Radiological Protection" (ICRP, 1994) and results in a dose conversion factor (DCF) of $9.5 \mu \mathrm{Sv}\left(\mathrm{kBq} \mathrm{h} \mathrm{m}^{-3}\right)^{-1}$ (Field, 2007), significantly higher than the conversion convention in use by the ICRP in 2007 and different from DCF $=12.92 \mu$ Sv $\left.(\mathrm{kBq} \mathrm{h} \mathrm{m})^{-3}\right)^{-1}$ applied in Field (2007, Table 7). An equilibrium factor of 0.366 is explicitly applied (Equation (9), Field, 2007 ) in addition to an assumed equilibrium factor of $F=0.4$ incorporated in the DCF. Effectively equilibrium factor is applied twice for calculation of received dose (Field, 2007, Table 7, reproduced Table 2).

\section{Current ICRP Guidelines and Reference Levels}

In 2010, the ICRP published a review of more recent epidemiological studies (ICRP, 2010) and concluded that a lifetime excess absolute risk of $14 \times 10^{-5} \mathrm{per}\left(\mathrm{mJ} \mathrm{h} \mathrm{m}^{-3}\right)$ should now be used as the nominal probability coefficient for radon and radon-progeny-induced lung cancer, replacing the previous value of $8 \times 10^{-5}$ per $\left(\mathrm{mJ} \mathrm{h} \mathrm{m}^{-3}\right)($ ICRP, 1993). Furthermore, the ICRP stated that radon and radon progeny should be treated in the same way as other radionuclides within the ICRP system of protection, that is doses from radon and its progeny should be calculated using ICRP biokinetic and dosimetric models.

RDPs are charged ions that rapidly combine with gasses and vapors in the atmosphere to form particles of a few nanometers in size. These particles may continue to combine with other sub-micron aerosol particles. When inhaled, the size of the particles to which the RDPs are attached determines the cells that are exposed to the alpha-radiation emit-

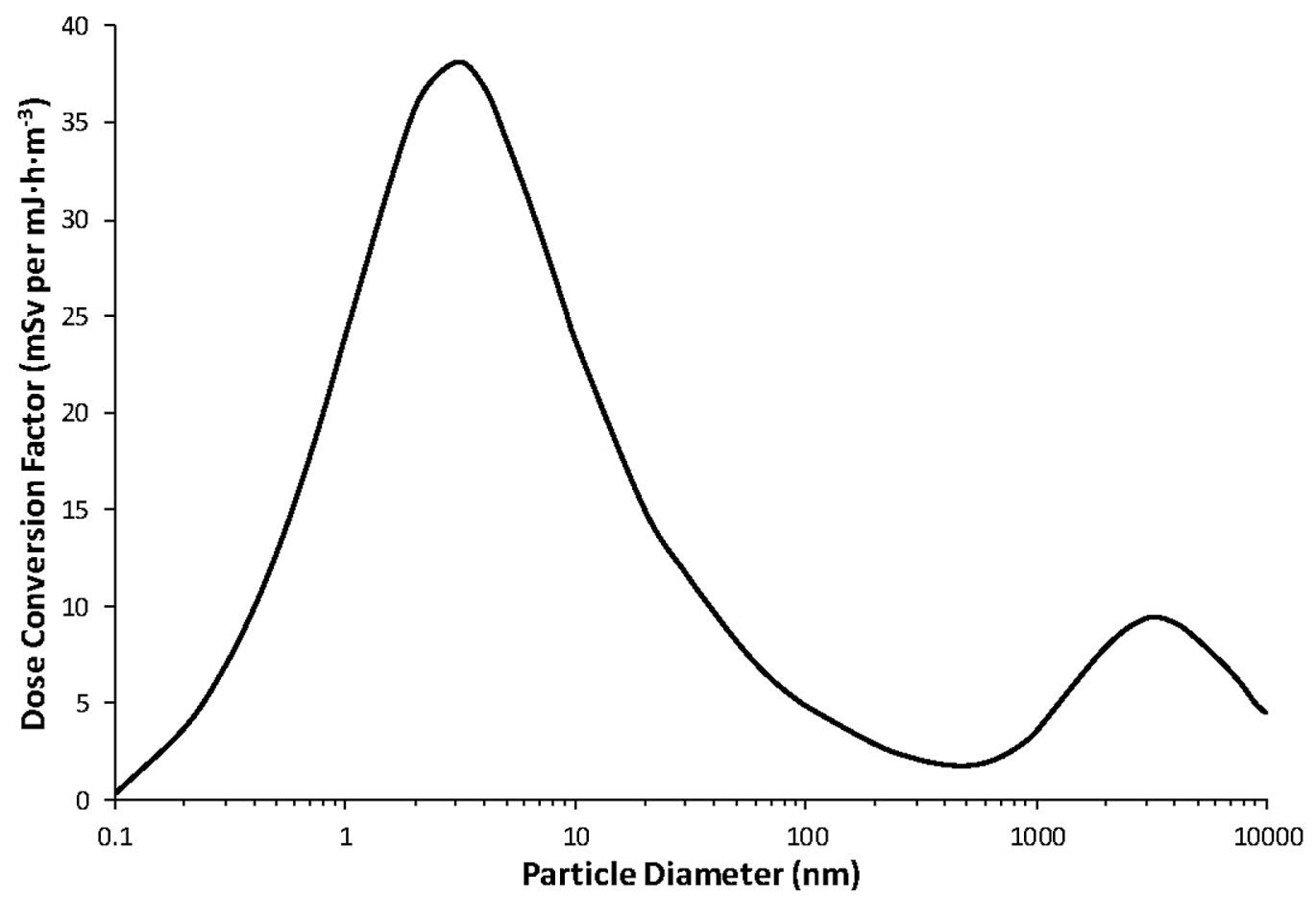

Figure 1. Effective dose per potential alpha energy exposure as a function of particle size of a monodispersed aerosol for a reference worker with an average breathing rate of $1.2 \mathrm{~m}^{3} \mathrm{~h}^{-1}$ following exposure to radon $\left({ }^{222} \mathrm{Rn}\right)$ progeny. Unit density and a unit shape factor were assumed and hygroscopic growth was not taken into account (fitted values from Figure A5 in ICRP 137 (ICRP, 2017). ted by the RDPs. Therefore, the size distribution of the aerosols to which the RDPs are attached is a critical factor when calculating dose using the ICRP biokinetic and dosimetric models. Figure 1 indicates that the most important size range is those aerosols with diameters between 0.1 and $500 \mathrm{~nm}$. Mines tend to have atmospheres with a greater proportion of larger particles compared with the much cleaner atmospheres of caves. A counter-intuitive consequence is that mines tend to have a lower equilibrium factor $(F=0.2$, ICRP 137) and DCF than caves $(F=0.57$, Cigna, 2005) resulting in a 3 times lower dose to mine workers than cave workers for the same Rn exposure. 
In 2017, the ICRP published new DCFs for the inhalation of radon and its progeny (ICRP, 2017). A tabulation of situation specific DCFs in ICRP 137 (Table 12.7) lists indoor workplaces as $5.7 \mathrm{mSv}\left(\mathrm{mJ} \mathrm{h} \mathrm{m}^{-3}\right)^{-1}\left(20 \mathrm{mSv} \mathrm{WLM}^{-1}\right)$ and for the specific case of tourist caves $6.7 \mathrm{mSv}\left(\mathrm{mJ} \mathrm{h} \mathrm{m}^{-3}\right)^{-1}\left(24 \mathrm{mSv} \mathrm{WLM}^{-1}, 15.4 \mu \mathrm{Sv}\left(\mathrm{kBq} \mathrm{h} \mathrm{m}^{-3}\right)^{-1}\right)$. In these calculations, the reference worker is assumed to spend two-thirds of the time in exercise. The ICRP now recommends a DCF of 3 $\mathrm{mSv}\left(\mathrm{mJ} \mathrm{h} \mathrm{m}^{-3}\right)^{-1}$ for miners and sedentary workers and $6 \mathrm{mSv}\left(\mathrm{mJ} \mathrm{h} \mathrm{m}^{-3}\right)^{-1}\left(14.0 \mu \mathrm{Sv}\left(\mathrm{kBq} \mathrm{h} \mathrm{m}^{-3}\right)^{-1}\right)$ for active indoor workers and workers in tourist caves, over four times greater than that previously recommended. These recommendations assume standard particle distributions and an equilibrium factor of 0.4 , which differs from the global average cave equilibrium factor of 0.57 (Cigna, 2005). The ICRP does note that in cases where aerosol characteristics are significantly different from typical conditions, sufficient, reliable aerosol data are available, and estimated doses warrant more detailed consideration, site-specific DCFs could be calculated.

The use of a site specific DCF in caves is challenging due to the high variability of parameters within a cave system. Jenolan Caves is one of a few cave systems where a site specific DCF may be calculated from known aerosol characteristics (Solomon, 2019) for a DCF of $13.27 \mathrm{mSv}\left(\mathrm{mJ} \mathrm{h} \mathrm{m}^{-3}\right)^{-1}$ for Temple of Baal cave or $5.67 \mathrm{mSv}\left(\mathrm{mJ} \mathrm{h} \mathrm{m}^{-3}\right)$

${ }^{-1}$ for Katies Bower chamber in Chifley Cave. These same two caves, Chifley and Temple of Baal, were selected for their different ventilation patterns to provide site-specific continuous measurements of Rn, Rn progeny, condensation nuclei, and equilibrium factor (Zahorowski et al., 1998) to estimate an annual average equilibrium factor of $F=0.55$, and therefore DCF $=19.3 \mu \mathrm{Sv}\left(\mathrm{kBq} \mathrm{h} \mathrm{m}^{-3}\right)^{-1}$.

\section{RADON MEASUREMENT METHODS}

Active measurement of $\mathrm{Rn}$ implies an active flow of air past the Rn detector, which typically requires a solid-state electronic detector to achieve accurate equilibrated measurements in 5 minutes. Passive measurement of Rn relies on $\mathrm{Rn}$ diffusing through a filter or into a chamber to reduce sensor sampling anomalies. A common passive Rn sensor is polyallyl di-glycol carbonate (PADC) plaque, also known as CR-39 or a nuclear track etch detector, which is capable of recording cumulative $\alpha$ particle decay from $\mathrm{Rn}$ in the chamber leaving a microscopic track that can be made visible by etching. The number of $\alpha$ particle tracks in the exposed plaque is proportional to the average $\mathrm{Rn}$ concentration multiplied by the exposure time, reported as a cumulative exposure $\left(\mathrm{Bq} \mathrm{h} \mathrm{m} \mathrm{m}^{-3}\right)$ typically over some months. Each track etch detector has a characteristic diffusion time of up to 1-2 days (Tate and Long, 2016) to establish a Rn concentration diffusion gradient between external and chamber. The track etch detector is calibrated for a linear response to Rn, after establishing a diffusion gradient and above a threshold of counted tracks, the minimum reporting level (MRL). When track etch detectors are deployed as a static cave Rn monitor (Solomon et al., 1996), the time required to establish an equilibrium diffusion gradient is small (1-2 days) compared to the total exposure time ( $\sim 90$ days), resulting in a small error. Passive Rn detectors are not suitable for use as personal dosimeters for walk-through cave workers where the dosimeter diffusion time is large (up to 1-2 days) compared to the exposure time (1-2 hours) typical for a cave tour.

There are also many passive digital Rn monitors designed for static indoor household use with an unknown time lag to establish a Rn diffusion gradient for accurate measurement. These monitors may be deployed for static real-time $\mathrm{Rn}$ measurements within caves. There are a few active digital Rn monitors with a continuous air-flow rate (Rn sniffer) suitable for the mobile monitoring of walk-through cave workers in a highly dynamic cave environment (10× Rn concentration in 4 hours, Figs. 4 and 5). If air flow direction is changed by the usual ventilation change driven by the diurnal temperature cycle, the equilibrium factor changes independently of Rn concentration because of different aerosol and condensation nuclei characteristics for different air sources.

In this study, radon activity was measured by recording at 1-hour integrated intervals using a Saphymo Alphaguard PQ2000 Pro radon monitor. Environmental sensors were placed above the $2.0 \mathrm{~m}$ high $\times 0.5 \mathrm{~m}$ wide passageway at Flitch of Bacon (FoB) drip water site near Chifley Cave exit to Grand Arch. Data was recorded at 15-minute intervals on a Datataker DT80 Series 2 data logger. Air flow direction and velocity data were obtained using a Gill Instruments Windsonic 2D sonic anemometer.

For Australian show caves including Jenolan Caves, Solomon et al. (1996) measured cave Rn exposure by placing passive track etch CR-39 detectors throughout the cave system, collected quarterly and calculated cave worker Rn exposure from time spent on particular cave tours to give seasonal, as well as cave specific, assessments. After 2001, subsequent Jenolan Caves Rn studies used active measurement techniques and targeted representative sites with differing ventilation characteristics in Chifley and Temple of Baal Caves (Barnes et al., 2001; Waring et al., 2017; Whittlestone et al., 2003; Zahorowski et al., 1998).

Average annual $\mathrm{Rn}$ concentration in Jenolan Caves, $1,021 \mathrm{~Bq} \mathrm{~m}^{-3}$ (Solomon et al., 1996) is low to moderate in comparison with the Australian average $610 \mathrm{~Bq} \mathrm{~m}^{-3}$ and other caves worldwide, $11 \mathrm{~Bq} \mathrm{~m}^{-3}$ to $47,419 \mathrm{~Bq} \mathrm{~m}^{-3}$ (Table 2). Average annual cave Rn concentration may mask the extreme variation from maximum to minimum of approximately two orders of magnitude (Field, 2007) and differ significantly from the actual average Rn exposure of cave workers. 
Table 2. Summary of international ${ }^{222}$ Rn literature (modified from Hyland and Gunn (1994) and Field (2007)) for average annual ${ }^{222} \mathrm{Rn}$ in caves and calculated dose to cave workers assuming hours worked underground (2,000 or 600 hours), equilibrium factor $(0.4$ or $\mathbf{0 . 5 7 )}$ and dose conversion factors. Figures for estimated dose reproduced from Field (2007) Table $7^{\mathrm{a}}$. Many of the national references include ${ }^{222} \mathrm{Rn}$ measurements from several sources ${ }^{\mathrm{b}}$.

\begin{tabular}{|c|c|c|c|c|c|}
\hline \multicolumn{2}{|c|}{$\begin{array}{l}\text { International Summary Cave }{ }^{222} \mathrm{Rn} \\
\text { Concentration and Received Dose }\end{array}$} & \multirow{2}{*}{$\begin{array}{c}\text { Table } 7^{\mathrm{a}} \\
\text { UG hours }= \\
2,000 \\
\text { Field } 2007 \\
\left(\mathrm{mSv} \mathrm{y}^{-1}\right)\end{array}$} & \multirow{2}{*}{$\begin{array}{c}\text { DCF } \\
\mu S v(k B q ~ h \\
\left.m^{-3}\right)^{-1}=14 \\
\text { UG hours }= \\
2,000 \\
\text { ICRP } 137 \mathrm{~F}=0.4 \\
\left(\mathrm{mSv} \mathrm{y}^{-1}\right)\end{array}$} & \multirow{2}{*}{$\begin{array}{c}\text { DCF } \\
\mu S v\left(k B q ~ ~ m^{-3}\right)^{-1} \\
=20\end{array}$} & \multirow[b]{2}{*}{ References } \\
\hline Country Cave & $\begin{array}{c}\text { Mean Annual } \\
{ }^{222} \mathrm{Rn} \text { Conc. } \\
\left(\mathrm{Bq} \mathrm{m}^{-3}\right)\end{array}$ & & & & \\
\hline Australia & 610 & $6(16)$ & 17 & 7 & Solomon et al. (1996) \\
\hline Jenolan Caves & 1,021 & $\ldots$ & 29 & 12 & Solomon et al. (1996) \\
\hline Jenolan Caves & 2,146 & $\ldots$ & 60 & 26 & this study \\
\hline Jenolan Caves, Chifley & 838 & $\cdots$ & 23 & 10 & Solomon et al. (1996) \\
\hline Jenolan Caves, Chifley & 4,578 & $\cdots$ & 128 & 55 & this study \\
\hline China & 141 & $1(4)$ & 4 & 2 & Wiegand et al. (2000) \\
\hline Shawan Cave, China & 47,419 & $\cdots$ & 1,328 & 569 & Wang et al. (2019) \\
\hline Czech Republic & 1,235 & $12(32)$ & 35 & 15 & Burian and Stelcl (1990) \\
\hline Great Britain & 2,907 & $27(75)$ & 81 & 35 & Hyland and Gunn (1994) \\
\hline Great Britain & 35,890 & 339 (927) & 1,005 & 431 & Gunn et al. (1991) \\
\hline Great Britain & 9,306 & $88(240)$ & 261 & 112 & Gillmore et al. (2000) \\
\hline Great Britain & 365 & $3(9)$ & 10 & 4 & Gillmore et al. (2002) \\
\hline Great Britain & 315 & $3(8)$ & 9 & 4 & Gillmore et al. (2002) \\
\hline Greece & 25,179 & $238(650)$ & 705 & 302 & Papastefanou et al. (1986) \\
\hline Hungary & 3,300 & $31(85)$ & 92 & 40 & Somogyi et al. (1989) \\
\hline Hungary & 2,468 & $23(64)$ & 69 & 30 & Lenart et al. (1990) \\
\hline Ireland & 4,127 & 39 (107) & 116 & 50 & Duffy et al. (1996) \\
\hline Japan & 11 & $0(0)$ & 0 & 0 & Miki and lauthora (1980) \\
\hline Malaysia & 596 & $6(15)$ & 17 & 7 & Gillmore et al. (2005) \\
\hline Poland & 1,166 & $11(30)$ & 33 & 14 & Przylibski (1999) \\
\hline Russia & 2,390 & $23(62)$ & 67 & 29 & Gunn (1991) \\
\hline Slovenia & 1,412 & $13(36)$ & 40 & 17 & Kobal et al. (1988) \\
\hline Slovenia & 965 & $9(25)$ & 27 & 12 & Kobal et al. (1987) \\
\hline $\begin{array}{l}\text { Postojna Cave LP, } \\
\text { Slovenia }\end{array}$ & 3,255 & $\cdots$ & 91 & 39 & Gregorič et al. (2014) \\
\hline $\begin{array}{l}\text { Postojna Cave BC, } \\
\text { Slovenia }\end{array}$ & 2,315 & $\cdots$ & 65 & 28 & Gregorič et al. (2014) \\
\hline $\begin{array}{l}\text { Postojna Cave GC, } \\
\text { Slovenia }\end{array}$ & 25,020 & $\cdots$ & 701 & 300 & Gregorič et al. (2014) \\
\hline Spain & 108 & $1(3)$ & 3 & 1 & Dueñas et al. (1998) \\
\hline Spain & 3,564 & $34(92)$ & 100 & 43 & Lario et al. (2005) \\
\hline Altamira Cave, Hall, Spain & 3,041 & $\ldots$ & 85 & 36 & Sainz et al. (2018) \\
\hline $\begin{array}{c}\text { Altamira Cave, PC room, } \\
\text { Spain }\end{array}$ & 3,286 & $\cdots$ & 92 & 39 & Sainz et al. (2018) \\
\hline Rull Cave, Spain & 1,762 & $\cdots$ & 49 & 21 & Pla et al. (2016) \\
\hline South Africa & 267 & $3(7)$ & 7 & 3 & Gamble (1981) \\
\hline Switzerland & 25,000 & $236(646)$ & 700 & 300 & Surbeck (1990) \\
\hline United States & 1,927 & $18(50)$ & 54 & 23 & Yarborough (1976) \\
\hline United States & 2,589 & $24(67)$ & 72 & 31 & Eheman et al. (1991) \\
\hline United States & 1,475 & $14(38)$ & 41 & 18 & Ahlstrand (1980) \\
\hline United States & 11,678 & $110(302)$ & 327 & 140 & Bashor (2004) \\
\hline Carlsbad Cavern, USA & 1,821 & $\cdots$ & 51 & 22 & Cheng et al. (2007) \\
\hline Hollow Ridge \#2, Florida & 4,733 & $\ldots$ & 133 & 57 & $\begin{array}{c}\text { Kowalczk and Froelich } \\
(2010)\end{array}$ \\
\hline Global average, Hakl et al. & 2,800 & $\ldots$ & 78 & 34 & Hakl et al. (1997) \\
\hline Global average, this study & 6,160 & $\ldots$ & 172 & 74 & this study \\
\hline total \# of caves ${ }^{\mathrm{b}}$ in Table 2 & 39 & $\ldots$ & $\ldots$ & $\ldots$ & $\ldots$ \\
\hline \# of caves $>1,000 \mathrm{~Bq} \mathrm{~m}^{-3}$ & 29 & $\cdots$ & $\cdots$ & $\cdots$ & $\cdots$ \\
\hline \# of caves $>20 \mathrm{mSv}^{-1}$ & $\ldots$ & $\cdots$ & 31 & 24 & $\cdots$ \\
\hline
\end{tabular}

${ }^{a}$ Doses of Table 7 in Field (2007) are derived by application of Eqn 9 (Field, 2007, DCF $=12.92 \mu$ Sv per $\mathrm{kBq} \cdot \mathrm{h} \cdot \mathrm{m}^{-3}, \mathrm{~F}=0.366$ ) citing Wiegand et al. (2000) where DCF was applied twice, contrary to (ICRP, 2019a). DCF assumes an equilibrium factor $F=0.4$. Divide figures in Table 7, Field (2007) by 0.366 to correct values in parentheses and compare with adjacent dose estimates.

${ }^{\mathrm{b}}$ Data quality control likely varies for each study conducted for each country which should be regarded as problematic.

${ }^{\circ}$ Global average equilibrium factor $F=0.57$ (Cigna, 2005) is applied. 
Annual average cave worker $\mathrm{Rn}$ exposure is a useful measure when converted to received dose for that individual to comply with workplace health standards. However, individual cave worker Rn cumulative exposure does not measure $\mathrm{Rn}$ concentration variations in different parts of the cave system, during different seasons or time of day to inform cave monitoring and mitigation measures.

Average annual $\mathrm{Rn}$ activity in a significant majority of caves from all countries, 28 from a total of 38 exceed the ICRP recommended action level of $1,000 \mathrm{~Bq} \mathrm{~m}^{-3}$ to reduce $\mathrm{Rn}$ exposure in the workplace (Table 2). Cave Rn activity and the ICRP recommended action level of $1,000 \mathrm{~Bq} \mathrm{~m}^{-3}$ have remained the same since 1994. However, the calculated received dose to cave workers has changed markedly from 1994 with a significant majority of full-time cave workers now expected to receive a radiation dose from $\mathrm{Rn}$ in excess of $20 \mathrm{mSv} \mathrm{y}^{-1}$, whether calculated with an ICRP assumed 2,000 workplace hours and equilibrium factor of 0.4 or a more likely 600 hours underground and equilibrium factor of 0.57 . Table 2 is a guide to Rn exposure and consequent dose using available annual averages. Actual Rn exposure and dose to cave workers need to be assessed for each cave and cave worker.

\section{SOURCE OF RADON IN CAVES}

Radon is known to accumulate in some homes or poorly ventilated basements where the underlying rock has an elevated concentration of $U$ necessary to maintain a high $R n$ flux to sustain elevated $R n$ concentrations in enclosed spaces. The short half-life of $\mathrm{Rn}$ (3.8 days) and short diffusion length through solid rock (Cigna, 2005) dictate that high Rn in an enclosed space must be replenished by direct diffusion from a high $U$ host rock with permeability (micro-cracking) or air flow from a relatively high $U$ or $R a$ source. Some granites and sandstones may have relatively high $U$ concentrations due to magmatic fractionation or hydrothermal concentration effects. In contrast, unaltered marine limestone typically has low $U$ concentration, yet may host cave chambers with very high $\mathrm{Rn}$ concentrations. The simple mechanism of direct diffusion or seepage from a high $U$ host rock applicable to enclosed poorly ventilated spaces in homes is unlikely to apply to the common high $\mathrm{Rn}$ found in limestone caves. The implicit direct $\mathrm{Rn}$ accumulation from cave host-rocks (Rn source) assumption in many studies (Fairchild and Baker, 2012; Fernandez-Cortes et al., 2015; Sainz et al., 2018; Wang et al., 2019) is not supported.

\section{Soil Source of Rn}

Cigna (2005) points to three fundamental mechanisms that favor a soil or cave sediment source of Rn compared with emanation from limestone hosting the cave void:

1. Low concentration of ${ }^{238} \mathrm{U}$ and ${ }^{226} \mathrm{Ra}$ in limestone host rock and relatively high concentration of ${ }^{238} \mathrm{U}$ and ${ }^{226} \mathrm{Ra}$ in clays,

2. Inability of $\mathrm{Rn}$ to escape the $\mathrm{CaCO}_{3}$ mineral lattice, unless very close to the surface $(0.02-0.07 \mu \mathrm{m})$, and

3. The effective diffusion length of $\mathrm{Rn}$ in soil via inter-granular pore space to open cracks and fissures is large enough to effectively transport $\mathrm{Rn}$ to the cave void with convective air transport.

A further uranium concentration mechanism favoring residual soils above karst is the concentration effect by dissolution of $\mathrm{CaCO}_{3}$ leaving the less soluble oxides and silicates including clays, effectively concentrating $\mathrm{U}$. Cave sediments may also form in-situ from limestone dissolution, however, an unknown proportion of the less soluble clays, oxides, and silicates may be transported to the cave and deposited by streamflow. Uranium concentration in seven cave sediment profiles from the UK (Bottrell, 1991) were found to be generally low (2-4 mg kg-1) with one exception at $15-16 \mathrm{mg} \mathrm{kg}^{-1}$ compared to external detrital sediments (16-24 $\mathrm{mg} \mathrm{kg}^{-1}$ ).

\section{Discriminating Between Cave Accumulation and Soil Source of Rn}

The most likely sources of $\mathrm{Rn}$ in caves are (1) an external soil source requiring transport of $\mathrm{Rn}$ to the cave or (2) the in-situ accumulation of Rn from internal cave sediments, limestone, drip-waters, or (3) from connected cracks, faults or open fissures to a high $U$ source rock. All sources of cave $\mathrm{Rn}$ are influenced by cave-air convective ventilation that may produce very similar seasonal cave $\mathrm{Rn}$ activity patterns. Cave $\mathrm{Rn}$ alone is not a good source discriminant. Time series correlation of $\mathrm{Rn}$ and $\mathrm{CO}_{2}$ showing a strong seasonal pattern (summer high) is used (Pla et al., 2016) to infer a common accumulation of $\mathrm{Rn}\left(513-3,500 \mathrm{~Bq} \mathrm{~m}^{-3}\right)$ and $\mathrm{CO}_{2}(565-4,065 \mathrm{ppm})$ from a cave source, assuming $\mathrm{CO}_{2}$ outgassing from speleothem growth air-flow Rn emanation from cave walls or sediments. An alternate soil source for $\mathrm{CO}_{2}$ and $\mathrm{Rn}$ transported to the cave by top-down dominant cave ventilation in summer is also possible. Isotopic measurement of $\delta^{13} \mathrm{C}-\mathrm{CO}_{2}$ is used (Waring et al., 2017) to discriminate between $\mathrm{CO}_{2}$ derived from speleothem outgassing in a cave $\left(\delta^{13} \mathrm{C}=-19 \%\right.$ VPDB $)$ and $\mathrm{CO}_{2}$ transported from soil $\left(\delta^{13} \mathrm{C}=-25 \%\right.$ VPDB) by summer chimney effect convective ventilation. In addition to $\delta^{13} \mathrm{C}-\mathrm{CO}_{2}$, another conservative gas tracer $\mathrm{N}_{2} \mathrm{O}$ is relatively abundant in soil gases and not formed or destroyed in caves. Together these gas tracers unequivocally attributes the source of Rn in Chifley Cave to the soil above (Waring et al., 2017). Synchronous measurement of Rn source flux, external and cave temperature, cave air flows, and multiple gas tracers can discriminate between $\mathrm{Rn}$ sources and $\mathrm{Rn}$ air-flow transport or dilution function. 


\section{Drip-Water Source of Rn}

Radon may also be transported from surface soils to the cave void by dissolved groundwater flow through joints, fissures and faults (Surbeck, 2005). For this mechanism to be effective groundwater flow to the cave must be rapid compared to the Rn half-life of 3.8 days. A further constraint on groundwater transport is the requirement for Rn solubility to change causing the outgassing of $\mathrm{Rn}$, potentially by a temperature increase of groundwater along the flow path.

\section{CAVE VENTILATION}

\section{Models of Cave Ventilation Patterns}

Cave physiography and temperature contrasts between cave air and external air temperature have a major influence over cave ventilation, particularly for caves with an upper and lower entrance separated by an elevation difference (Fig. 2). This configuration may be described as a chimney effect cave with the physics driving cave ventilation described in detail in the literature (Atkinson et al., 1983; Badino, 2010; Covington and Perne, 2016; Wigley and Brown, 1971; Wigley and Brown, 1976). In winter, cave air temperature is typically warmer than external air causing the less dense and relatively warm cave air to rise and expel to the external atmosphere. The converse summer air flow is in the opposite direction due to relatively cool cave air sinking to expel through the lower cave opening. Bi-directional convec-

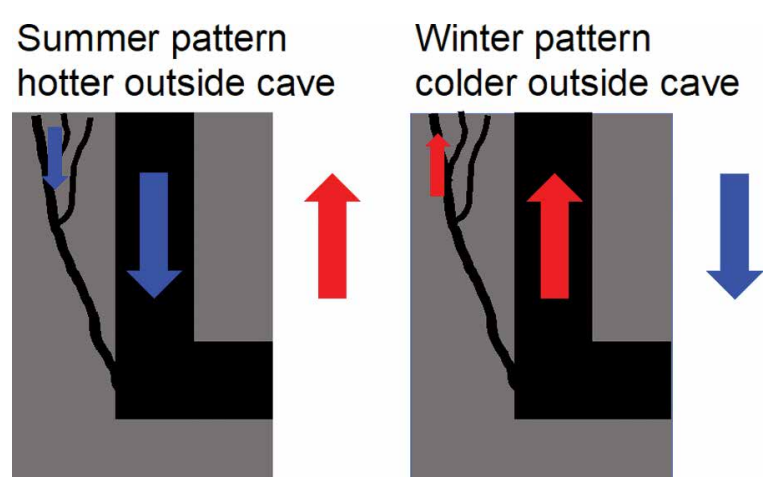

Figure 2. Illustration of chimney effect ventilation pattern where ventilation through a cave with 2 unequal elevation openings to the external atmosphere. A relatively constant cool cave temperature implies a dominant downward air flow in summer, when the external temperature is normally hotter than the cave temperature, driving convective ventilation through the cave. The converse pattern holds in winter. On any day, the temperature difference between cave and the external atmosphere may drive convective cave ventilation in either or both directions. tive air flow through the cave is proportional to the elevation difference between upper and lower openings, as well as the magnitude of the temperature contrast. On any single day air flow through the cave may be in both directions due to relative temperature being both higher and lower than cave temperature. Diurnal bi-directional cave air flow is most likely in spring and autumn where external temperature contrast is both positive and negative with respect to cave temperature. A chimney effect summer ventilation pattern from top to bottom along the major cave void path also induces a slight suction in the cave to draw air slowly into the cave through minor openings, cracks, and fissures.

Covington and Perne (2016) extends the cave morphologycave ventilation link to include an additional five variants where multiple entrances or exits are considered, relative position of the cave void to entrance or the connection to a large cave chamber via a small surface opening. A simple classification (Fig. 3) is based on geometries described in Covington and Perne (2016), number of entrances or exits (1EE or 2EE), relative position of cave void compared to those equal elevation entrances as either $\cap$ shape or $\cup$ shape or the cave chamber elevation relative to a single cave entrance. Relative position of the cave chamber to entrance may be described as either a summer cold air trap (SCAT), if the entrance is higher, or a winter warm air trap (WWAT), if the entrance is lower. Another mechanism to induce cave airflow is barometric pumping (Barometric), where a large cave chamber or network is connected to the surface via a single opening.

For single opening caves where the air mass is warmer than the external temperature, typically in winter, warm air may exit the cave through a major upper opening with replacement dense cool air seepage into the cave through soil, restricted openings, or fissures. The term seepage, or air seep, is used to describe slow air flow caused by air density contrast along a temperature gradient between different temperature air masses, not as a substitute term for diffusion. In winter, relatively dense cold air on the ground surface and in soil with high Rn may seep into near surface caves along small cracks and fissures if cave temperature is greater than external temperature, typical for a SCAT configuration.

A summer cold air trap type cave may be close to the surface with a single entrance or exit above the main chamber, as shown in Figure 3. Having less air exchange in summer for a SCAT configuration is likely because of a stable temperature profile. The stable temperature profile through a SCAT cave in summer is from relatively cold air at the base of the isolated SCAT chamber to relatively warm on the surface above. This stable temperature profile does not induce $\mathrm{Rn}$ transport from the soil above a SCAT cave in summer. In winter, the surface temperature is often colder than the relatively warm cave below. This winter temperature profile is unstable causing cold, dense (soil) surface air to seep into the cave below through minor cracks and fissures, transporting Rn from soil to SCAT type cave in winter, resulting in a summer low, winter high seasonal Rn pattern for SCAT type cave morphologies.

Temperature contrast between cave and external air drives convective cave ventilation on different physical and temporal scales. The magnitude of air mass flow under chimney effect ventilation is much greater and ubiquitous than 
$2 \mathrm{EE}$

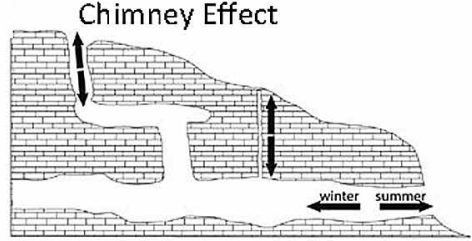

$2 \mathrm{EE}$

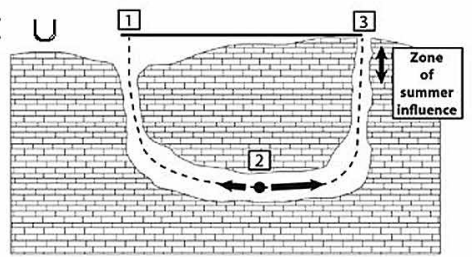

2EE $\cap$

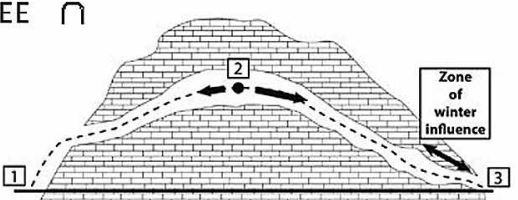

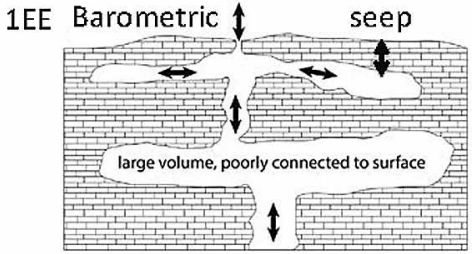

$1 \mathrm{EE}$

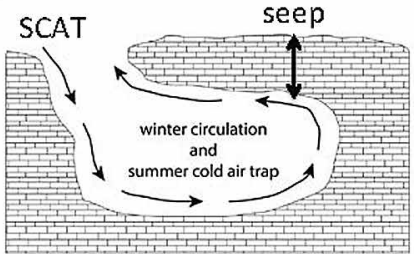

$1 \mathrm{EE}$

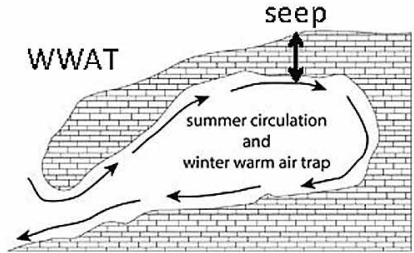

Figure 3. A modification of cave classification from Covington and Perne (2016) with morphology affecting ventilation pattern. coming off the Grand Arch and an upper opening on the ridge in a surface doline (Elder Cave) $62 \mathrm{~m}$ above the lower opening. The minimum path length between openings is $536 \mathrm{~m}$ and cave volume $9,587 \mathrm{~m}^{3}$ along this path (Zlot and Bosse, 2015). Radon and $\mathrm{CO}_{2}$ measurements shown in Figures 4 and 5 are from a cave chamber, Katies Bower, $120 \mathrm{~m}$ from the lower cave entrance, in the Grand Arch and one quarter of the total path length $(536 \mathrm{~m})$. Measurements of air flow, cave temperature, and pressure are from an instrument site in a $2 \mathrm{~m}$ high $\times 0.5 \mathrm{~m}$ wide passage called the Flitch of Bacon, $75 \mathrm{~m}$ from the Grand Arch (Figs. 4, 5, and 6). There are many extended side passages including Jubilee Cave without a direct opening to

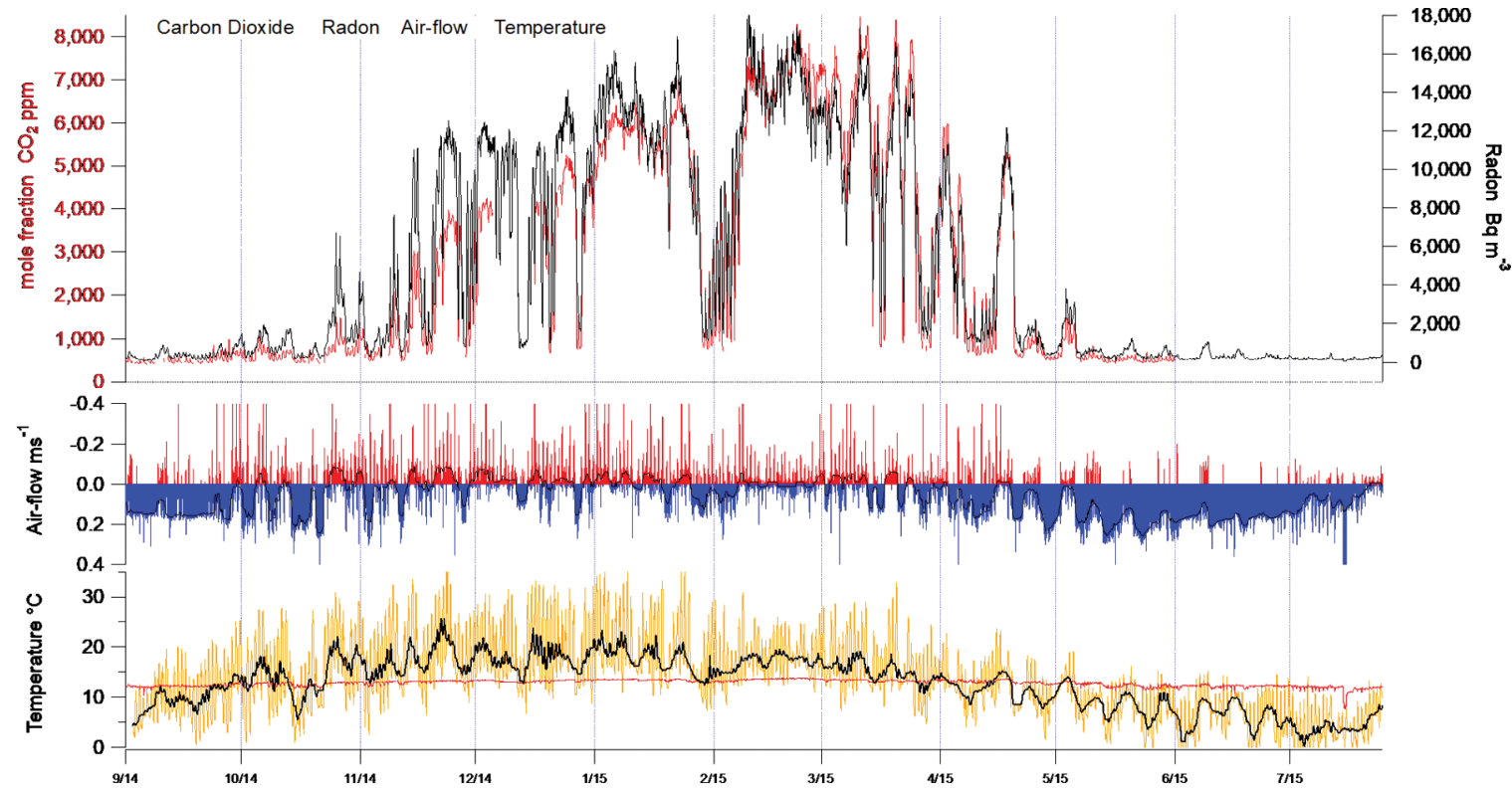

Figure 4. Radon and $\mathrm{CO}_{2}$ annual cycle. Synchronous seasonal variation at Lower Katies Bower, in Chifley Cave from September 2014 to September 2015. Rn continuous active integrated air sample recorded at 1-hour intervals, $\mathrm{CO}_{2}$, and temperature at 15-minute intervals. Winter air-flow pattern (blue) reduces Rn concentration and summer pattern (red) increases $\mathrm{Rn}$. The air-flow magnitude and direction is determined by the temperature contrast between cave temperature (red line) and external temperature (yellow line). The diurnal temperature range is often greater and less than cave temperature in a single day, causing a diurnal reversal of air flow. A 24-hour moving average of external temperature (black) removes the diurnal temperature variation to reveal a synoptic temperature pattern. the surface. An alternate lower passage connection to the Grand Arch through Imperial cave has a sealed door except for tour groups to pass, approximately three visits per day.

The Jenolan Caves complex has been mapped at high resolution $(3 \mathrm{~cm})$ using mobile LIDAR (Zlot and Bosse, 2014) with the full 3D dataset available (Zlot and Bosse, 2015). An excerpt from the 3D data (Zlot and Bosse, 2015) shows the north side cave 


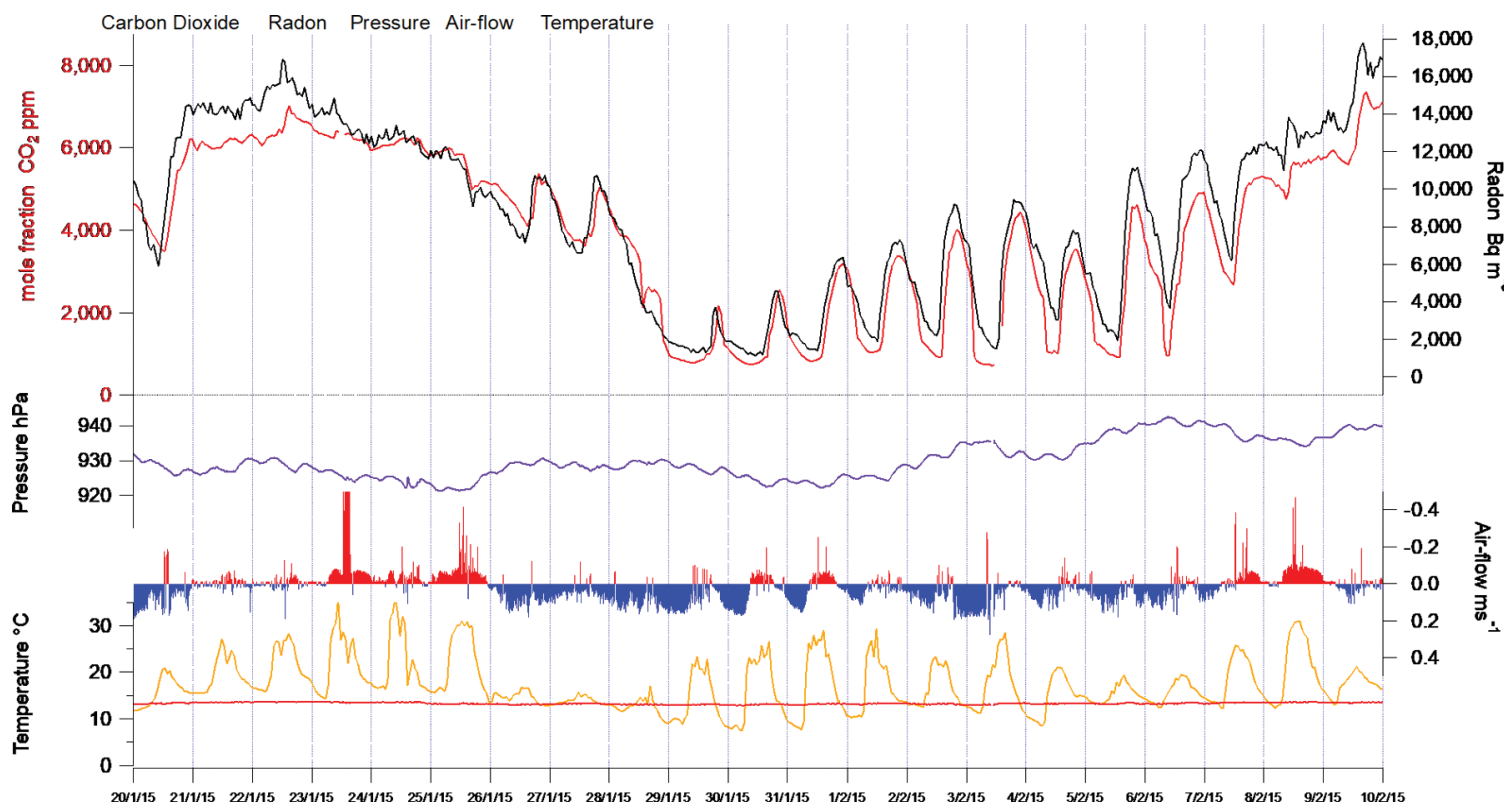

Figure 5. Radon and $\mathrm{CO}_{2}$ diurnal cycle. Synchronous variation over 20 days for $\mathrm{Rn}$ and $\mathrm{CO}_{2}$ at Lower Katies Bower, in Chifley Cave from January 20, 2015 to February 10, 2015. Rn continuous integrated air sample recorded at 1-hour intervals, $\mathrm{CO}_{2}$, air flow, temperature, pressure at 15-minute intervals. An unusual 3-day period of cold external temperatures in summer causes air flow to reverse direction (blue) reducing Rn concentration then returning to a diurnal pattern of bi-directional air flow. The air-flow magnitude and direction is determined by the temperature contrast between cave temperature (red line) and external temperature (yellow line). The diurnal temperature range is often greater and less than cave temperature in a single day, causing a diurnal reversal of air flow. A 24-hour moving average of external temperature (black) removes the diurnal temperature variation to reveal a synoptic temperature pattern.

mer and low $\mathrm{Rn}$ in winter as a result of chimney effect ventilation (Table 3). The common summer-high pattern of cave Rn activity is also represented in common summer-high estimated doses to Guides (Solomon et al., 1996). The alternate winter-high pattern of cave Rn is observed in Shawan (Wang et al., 2019) and Altimira Caves (Sainz et al., 2018). Both caves are very close to the surface with a single entrance-exit. Seasonal preferential seepage of cold air in soil through the epikarst above the cave due to temperature contrast in winter may explain the winter high $\mathrm{Rn}$ pattern for these shallow caves (Table 3). Both seasonal patterns show a strong correlation between cave $\mathrm{Rn}$ and $\mathrm{CO}_{2}$, suggesting a common external soil source of both gases.

Links between cave $\mathrm{Rn}$ activity and temperature contrast (external $\mathrm{T}$-cave $\mathrm{T}$ ) are well known and widely attribut-

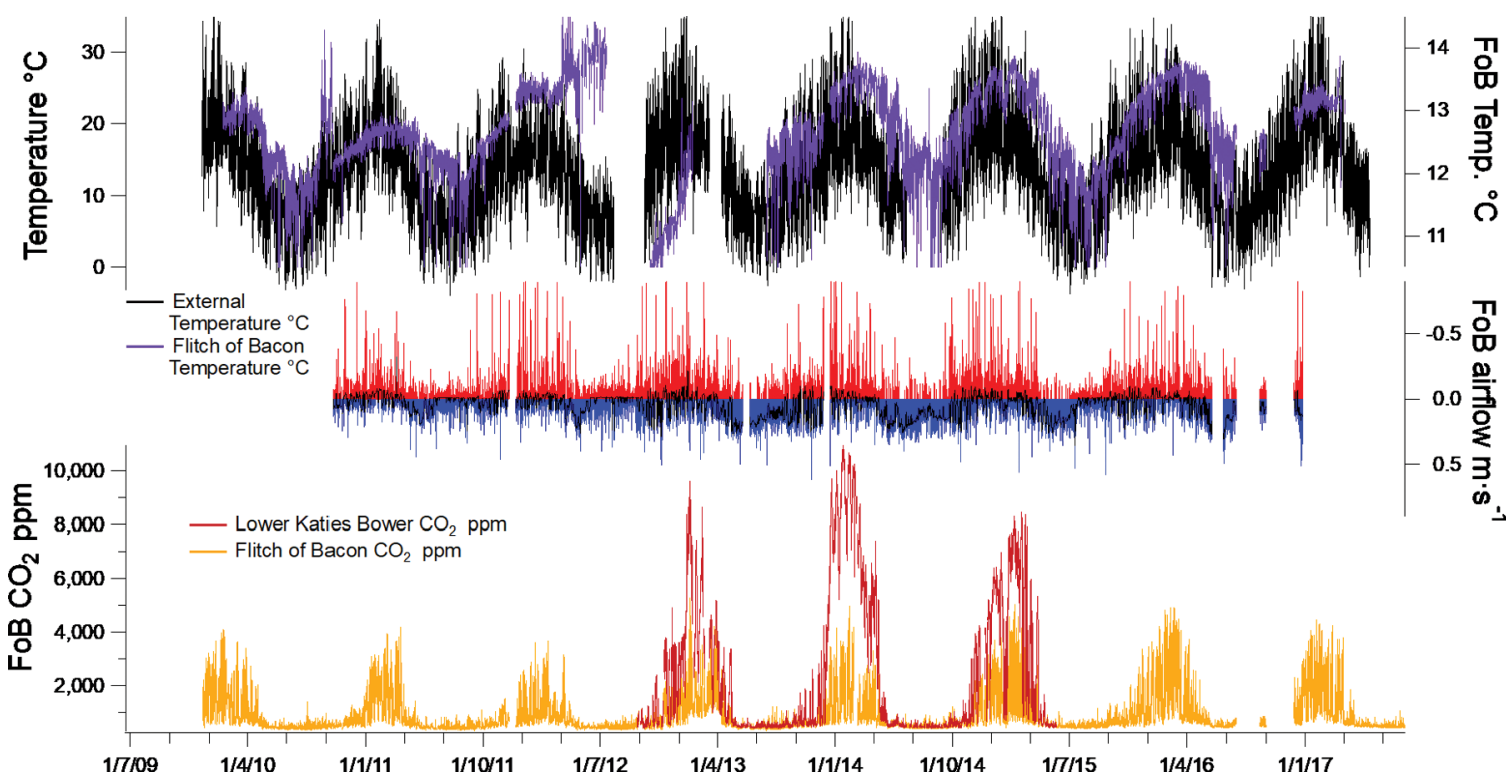

Figure 6. Temperature difference, cave airflow, and $\mathrm{CO}_{2}$ multi-year comparison. Synchronous variation (15 min) over 8 years for $\mathrm{CO}_{2}$ at Flitch of Bacon (FoB) and Lower Katies Bower (LKB) sites with 45-meter separation in Chifley Cave from 1 July 2009 to 20 August 2017. Cave temperature measured at FoB (purple) has a seasonal variation of $<3{ }^{\circ} \mathrm{C}$ compared to the external seasonal variation of around $30^{\circ} \mathrm{C}$. Cave temperature recorded between February 2012 and July 2013 may be unreliable due to water saturation of co-hosted humidity sensor. Short data gaps $<2$ months due to sensor failure are interpolated by modeling with adjacent years for construction of Table 4 . 


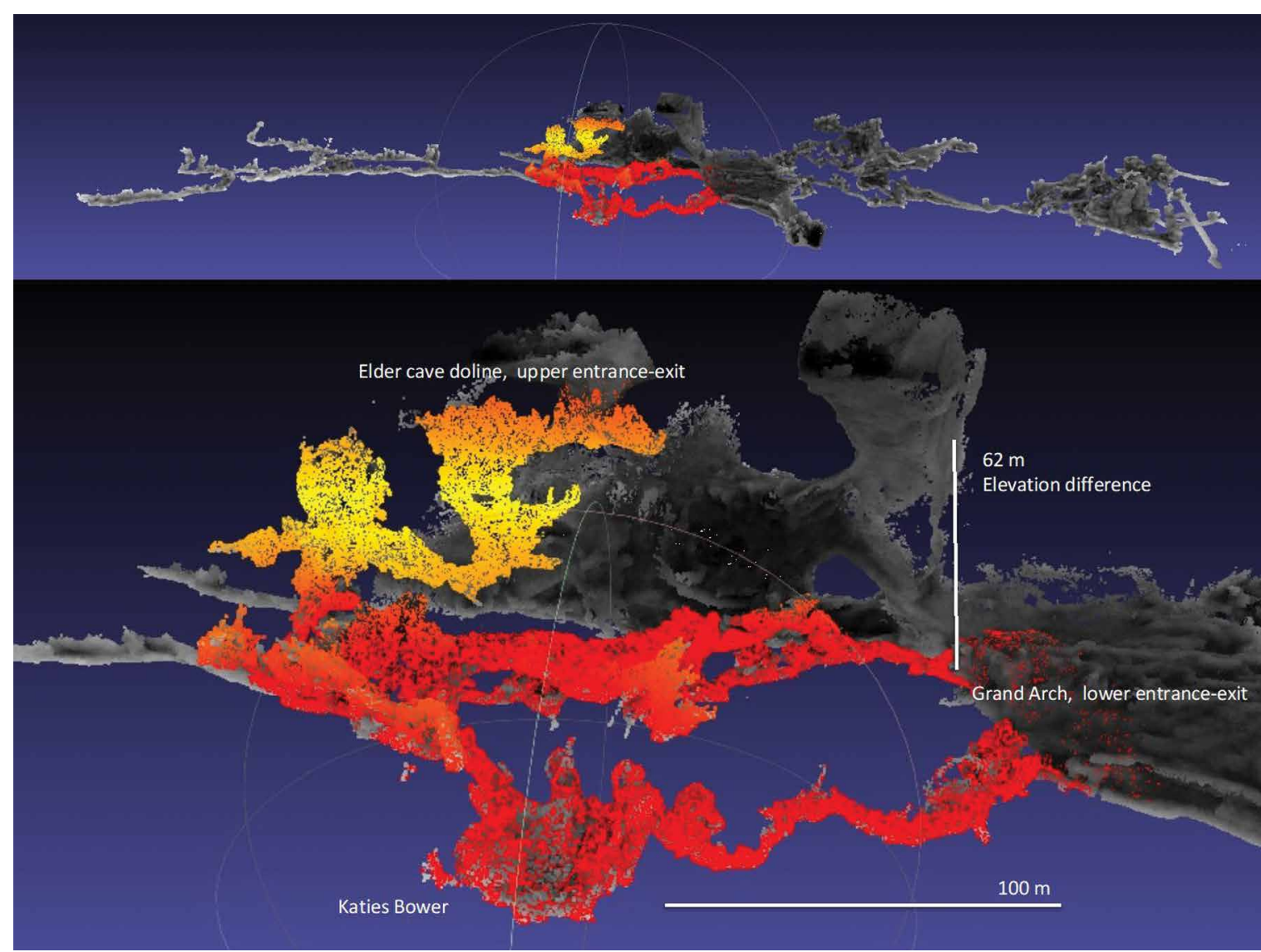

Figure 7. Oblique view of air-flow path between Elder cave doline upper entrance-exit and the lower Grand Arch entrance-exit. able to cave ventilation (Gregorič et al., 2014; Kowalczk and Froelich, 2010; Wigley and Brown, 1976). However, the source of $\mathrm{Rn}$ is often assumed to be by accumulation inside the cave with seasonal cave $\mathrm{Rn}$ concentration patterns caused by dilution with winter dominant cave ventilation of external low Rn air.

Lower Katies Bower chamber (Chifley Cave) Rn activity has a very strong seasonal bias with high $\mathrm{Rn}$ in summer and low Rn in winter (Fig. 4). Rn concentration closely correlates with $\mathrm{CO}_{2}$ concentration on a time scale of $<1$ hour (Fig. 5) for a 20-day period in summer 2015 suggesting a common source (Waring et al., 2017). Both $\mathrm{Rn}$ and $\mathrm{CO}_{2}$ cave concentrations are a function of soil source concentration and chimney effect ventilation. The 1 month delay in $\mathrm{CO}_{2}$ rise in the cave is likely caused by a delayed soil $\mathrm{CO}_{2}$ respiration response to an increase in soil biological primary productivity from spring soil warming compared to inorganic constant rate production of $\mathrm{Rn}$ in the soil.

\section{Temperature Difference and Air Flow Influence on Cave $\mathrm{CO}_{2}$ and $\mathrm{Rn}$}

$\mathrm{Rn}$ activity in Chifley Cave is dependent upon the temperature difference between cave and external air to drive cave ventilation measured as bi-directional air mass transfer, shown as weekly integration increments in Figure 8 . When measured at the 'Flitch of Bacon' (FoB) passage, the weekly integrated seasonal temperature pattern is symmetrically distributed with external temperature in excess of FoB cave temperature in summer and similarly in deficit in winter (Fig. 8). If integrated over a year from July $1^{\text {st }}$ to June $30^{\text {th }}$ inter-annual comparisons of temperature difference are very close to evenly balanced with a very small bias to warmer cave temperatures (Table 4).

Air velocity into or out of Chifley Cave is also measured at 'Flitch of Bacon' passage. The orthogonal hewn passage at FoB is $2.0 \mathrm{~m}$ high by $0.5 \mathrm{~m}$ wide simplifying calculation of air mass transfer from the Grand Arch entrance and exit. In stark contrast to the even temperature distribution, air flow driven by temperature difference is highly biased favoring winter air flow (Fig. 8). The ratio of volume of air moving into Chifley Cave from the Grand Arch (winter pattern) ranges from 2-5 times greater (Table 4) than the volume of air flowing out of Chifley Cave (summer pattern). The seasonal asymmetrical airflow bias implies cave temperature is approximately $5^{\circ} \mathrm{C}$ warmer than the average external temperature (Fig. 8).

Karst rock mass temperature is balanced by a geothermal heat flux from below and heat loss (winter) from above that approximates surface temperature. Caves provide air flow, water, and heat transfer pathways for temperature equilibration to extend the depth of average surface temperature influence to the depth of the cave system (Luetscher and Jeannin, 2004). In karst, a negative geothermal gradient close to the surface where temperature decreases with depth, has a deeper inflection point before resumption of a positive geothermal gradient to the Earth's interior. Air flow through caves and karst aquifers provide heat transfer mechanisms to establish a long-term stable near surface geothermal gradient as a bal- 
Waring, Hankin, Solomon, Long, Yule, Blackley, Werczynski, and Baker

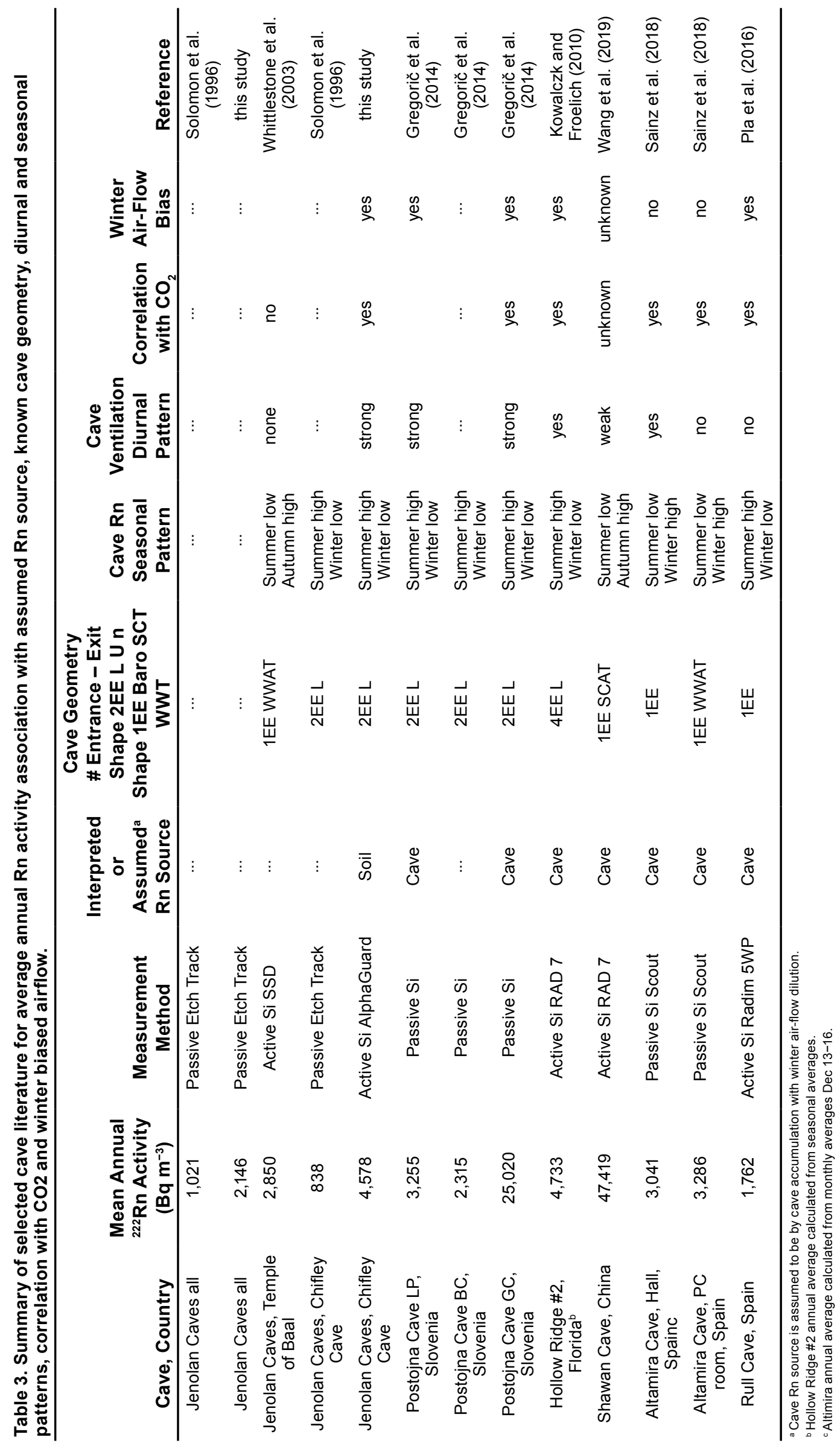




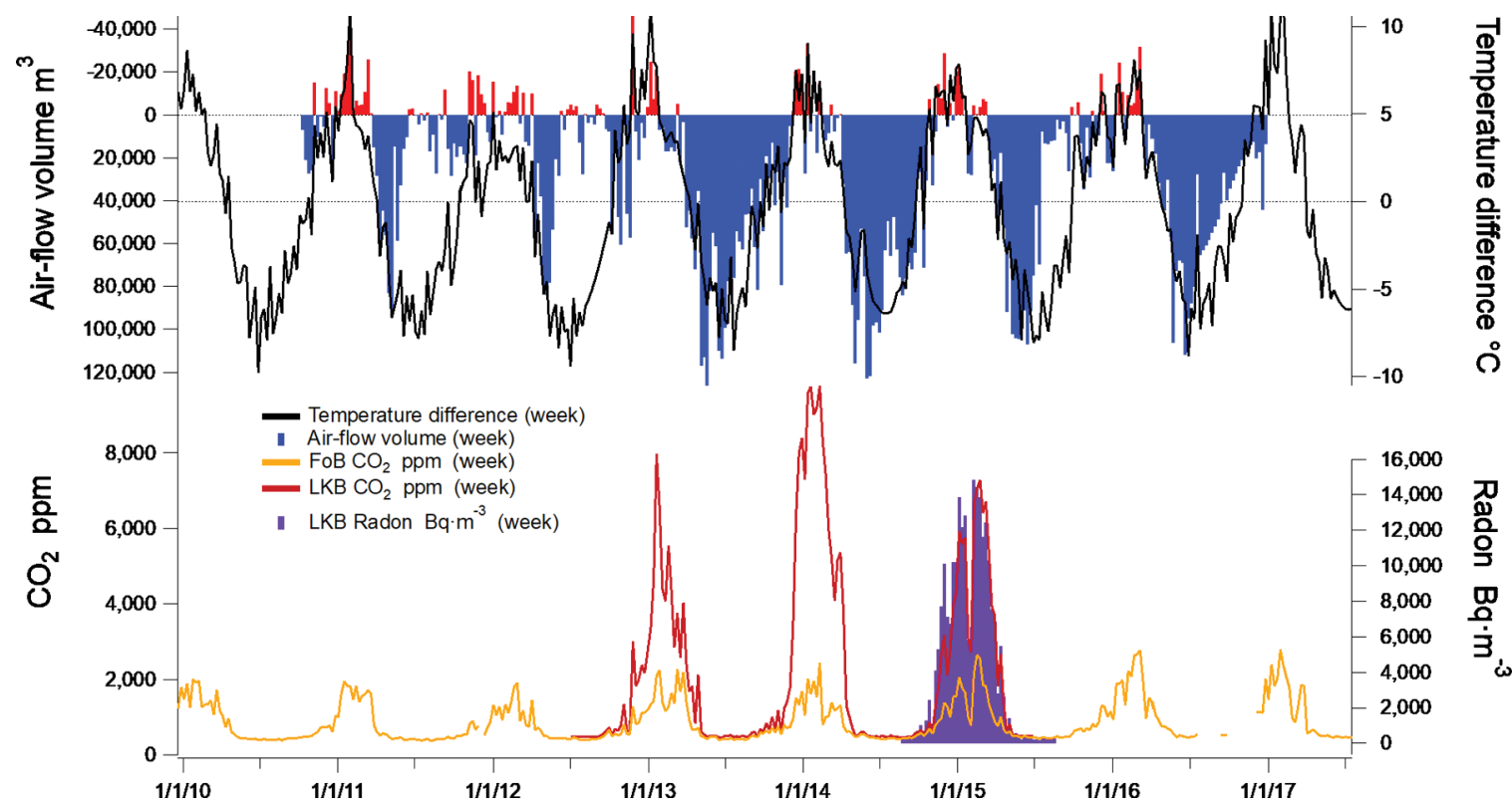

Figure 8. Weekly aggregates of 15 minute and hourly sensor data illustrates a balanced seasonal temperature difference (external temperature-cave temperature) compared to a biased seasonal airflow through Chifley Cave. The strong winter pattern airflow bias from the bottom up flushes $\mathrm{Rn}$ and $\mathrm{CO}_{2}$ from Chifley Cave. A warmer cave temperature of approximately $5{ }^{\circ} \mathrm{C}$ is implied by the biased seasonal airflow. $\mathrm{Rn}$ and $\mathrm{CO}_{2}$ are drawn into Chifley Cave from the soil above during top down summer pattern airflow. Average weekly $\mathrm{CO}_{2}^{2}$ measured at Flitch of Bacon passage during summer has a maximum close to 2,000 ppm whereas $\mathrm{CO}_{2}$ measurements at Lower Katies Bower, $45 \mathrm{~m}$ further into Chifley Cave has a maximum that ranges between 7,000-10,000 ppm. ance between average surface temperature and the geothermal heat flux from below.

The annual average surface temperature is therefore expected to be the same as the annual average cave air temperature, plus a component due to heat flux from the Earth's interior. Cave air temperature varies depending on position within the cave and the geothermal gradient. For Jenolan Caves, cave air temperature

vertical profile varies from $12^{\circ} \mathrm{C}$ at the lowest elevation in Chifley Cave $(\mathrm{FoB})$ to a $16^{\circ} \mathrm{C}$ soil temperature above Chifley Cave (Table 4). The average temperature for a column of air through Chifley Cave is $2-5^{\circ} \mathrm{C}$ warmer than temperature at FoB due to geothermal heating. Similarly, external temperature varies depending on position of the weather station with respect to local topography, potentially creating a temperature offset from the true average temperature of the column of air in a cave or externally due to thermometer location.

The small net annual average temperature difference between a column of air inside the cave and an external column of air produces a large net annual volumetric air flow bias (2-5:1) favoring the winter ventilation pattern that flushes Rn from caves with ambient air (Fig. 8). A model (Greene et al., 2019) of external temperature variation at Jenolan Caves shows a small temperature increase $\left(0.17^{\circ} \mathrm{C}\right)$ from 2008 to 2018 consistent with an increase in temperature from global warming. Cave temperature from Flitch of Bacon increases by a smaller amount $\left(0.1^{\circ} \mathrm{C}\right)$ over the same period, though with less certainty due to cave temperature data record gaps (Fig. 6).

Comparison of average annual $\mathrm{CO}_{2}$ concentration measured at Lower Katies Bower (Table 4) from 2013-2014 $(1,812 \mathrm{ppm})$ to $2014-2015$ (2,909 ppm) shows an inter annual increase of $60 \%$ before reducing by $30 \%$ in $2015-2016$ $(2,195 \mathrm{ppm})$. A small variation in annual average external temperature, amplifies net air flow causing a large impact on cave $\mathrm{CO}_{2}$ concentration (Table 4). Inter-annual variations in Rn activity of approximately $60 \%$ may also be expected from a small $\sim 0.5{ }^{\circ} \mathrm{C}$ change in average external temperature. Warming external temperature due to climate change over decades will decrease the cave minus external temperature difference causing a decrease in winter pattern airflow and an increase in cave Rn activity.

\section{Cave $\mathrm{CO}_{2}$ as a Proxy for Rn}

Chifley Cave $\mathrm{Rn}$ and $\mathrm{CO}_{2}$ concentration closely correlates (Fig. 9, $R^{2}=0.94$ ) within a measurement timescale of $<1$ hour, over 20 days because of a mutual soil source. Over a longer seasonal time frame, the soil source $\mathrm{CO}_{2} / \mathrm{Rn}$ ratio changes slightly due to primary biological productivity only affecting $\mathrm{CO}_{2}$ from bacterial and root respiration and not $\mathrm{Rn}$. Individual rain events and longer low rainfall periods may also affect soil moisture, and consequently, soil $\mathrm{CO}_{2}$ concentration and the $\mathrm{CO}_{2} / \mathrm{Rn}$ source ratio (Waring et al., 2017). In caves where there may not be a mutual source of $\mathrm{Rn}$ and $\mathrm{CO}_{2}$ or where chimney effect ventilation is not evident, a $\mathrm{Rn}-\mathrm{CO}_{2}$ correlation is unlikely to apply (e.g., Temple of Baal, Jenolan Caves). $\mathrm{CO}_{2}$ in caves may also have an inorganic source from limestone dissolution in the epikarst, speleothem growth, or from the breath from high numbers of cave visitors to change the cave $\mathrm{CO}_{2} / \mathrm{Rn}$ ratio.

With the exception of the Temple of Baal, increases in $\mathrm{CO}_{2}$ associated with visitation at Jenolan are typically relatively short-lived and quickly return to the pre-tour level (Baker, 2014). Consequently, the $\mathrm{CO}_{2}$ from cave visitors would not 


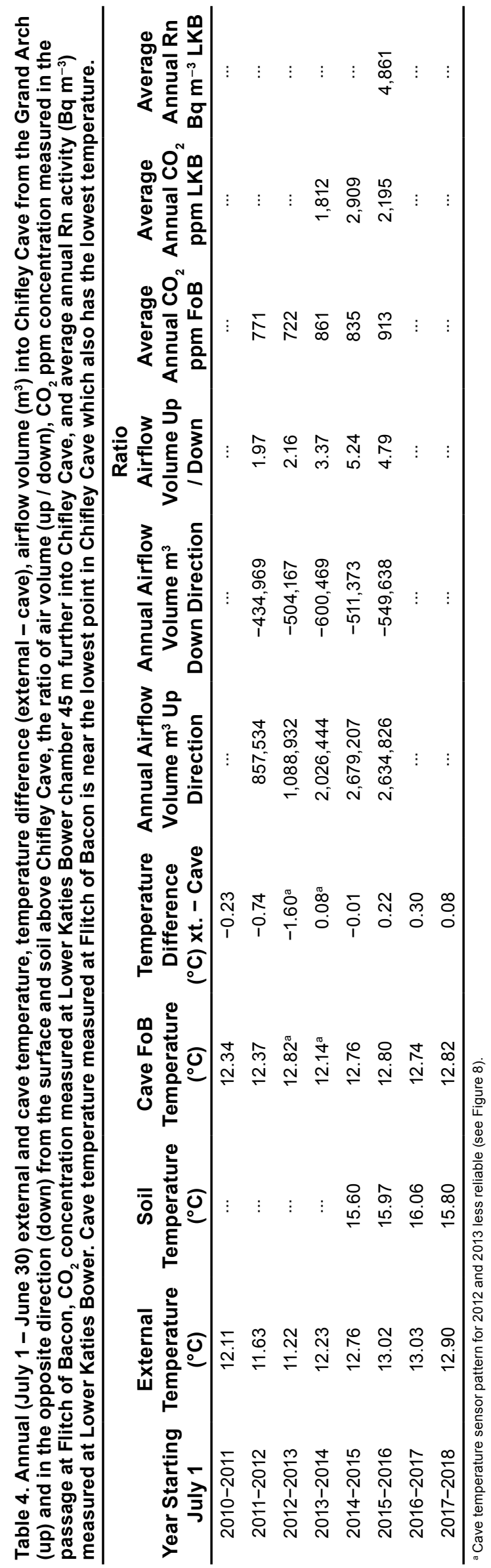

be expected to significantly skew the $\mathrm{CO}_{2} / \mathrm{Rn}$ ratio if averaged more broadly across a 24 hour or weekly timeframe. Ten years of monitoring exhibition caves at Jenolan shows that 8 caves exhibit strong seasonal variations in $\mathrm{CO}_{2}$ with a summer maximum and a winter minimum, with the exception the Temple of Baal (Baker, 2014).

For most exhibition caves at Jenolan, including Chifley Cave, the breath from cave visitors and soil source $\mathrm{CO}_{2} / \mathrm{Rn}$ variation is likely to be small, permitting $\mathrm{CO}_{2}$ to be used as a proxy measurement for $\mathrm{Rn}$.

\section{POTENTIAL MITIGATION STRATEGIES TO REDUCE RADON EXPOSURE}

The ICRP (ICRP, 2019b) provides summary recommendations for workplaces:

If cave Rn activity levels are anticipated to be elevated, cave managers are expected to monitor cave Rn activity, if possible reduce workplace $\mathrm{Rn}$ activity and take action to reduce worker exposure to $\mathrm{Rn}$ in the workplace (cave).

ICRP 126 (ICRP, 2014) Executive summary:

" $(\mathrm{m})$ Characterisation of the exposure situation is also a prerequisite for application of the optimisation principle. This principle is the driver for controlling radon exposure in order to maintain or reduce exposure to a level that is as low as reasonably achievable [ALARA], taking the prevailing economic and societal circumstances into account. As with the control of other sources of radiation, the Commission recommends the use of a source-related individual dose restriction in conjunction with the optimization of protection."

Prerequisite characterization of the exposure situation implies that cave $\mathrm{Rn}$ monitoring is sufficient for applying optimization principles (mitigation measures). Continuous real-time $\mathrm{Rn}$ monitoring to track diurnal, seasonal, and cave location specific variable $\mathrm{Rn}$ activity is absent from most tourist caves. Reduction of $\mathrm{Rn}$ in the workplace (optimization) may be possible, applying ALARA principles, before restriction of cave worker hours exposed to elevated Rn activity.

\section{For workplaces where radon levels exceed $1,000 \mathrm{~Bq} \mathrm{~m}^{-3}$, ICRP Publication 126 (ICRP, 2014) states:}

"In workplaces where, despite all reasonable efforts to reduce radon exposure, individual doses persist above $10 \mathrm{mSv}^{-1}$, the workers should be considered as occupationally exposed and their exposure should be managed using the relevant radiological protection requirements established for occupational exposure: identification of the exposed workers, information, training, dose monitoring (in doses or potential alpha energy concentration) and recording, and health surveillance. In any case, the individual doses should not exceed the upper value of the 1-20 mSv band."

\section{Limiting Time Exposed to Rn}

Different approaches to mitigating worker exposure to high $\mathrm{Rn}$ in caves may be achieved by limiting the underground hours of Rn exposure for cave workers. Some cave systems may be able to adjust cave worker hours / schedule to lower cave worker dose within an acceptable range, for others this may be very difficult. Some workers may not wish to work greater or fewer underground hours or assume a greater perceived health risk. 


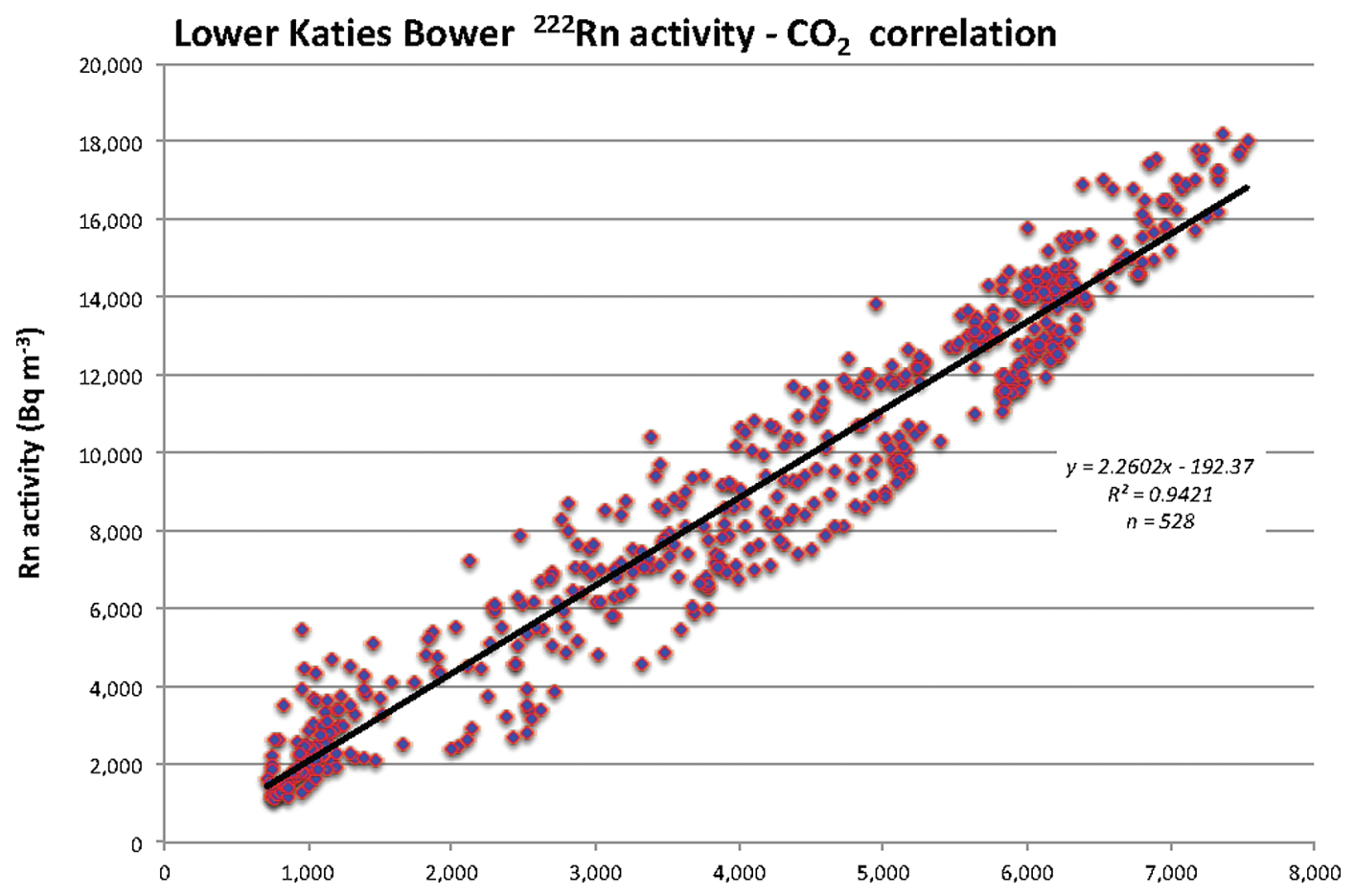

Figure 9. Radon activity vs. $\mathrm{CO}_{2}$ concentration correlation during the time period January 20, 2015 to February 10, 2015, shown in Figure 4.

\section{Passive Modifications to Cave Ventilation}

If cave managers wish to reduce the worker exposure to high Rn concentration by controlling a cave's natural ventilation, the source(s) of $\mathrm{Rn}$ makes a material difference, whether $\mathrm{Rn}$ is excluded from the cave and reduced, or trapped in the cave and increased. The natural ventilation regime in many show caves may have been significantly altered by existing facilities, air flow enhanced by passage widening or restricted by construction of sealed doors. Intervention in the ventilation regime for the purpose of reducing $\mathrm{Rn}$ exposure needs to consider the

possible consequences on cave environments, speleothems, and biota to prevent deleterious effects.

Based on a detailed knowledge and understanding of Rn dynamics in a typical chimney effect cave (Chifley Cave), it is possible to devise a strategy to exclude $\mathrm{Rn}$ from caves originating from the soil above and enhance the natural flushing of air by opening and closing sealed doors in synchrony with external temperature changes. For example, when the external temperature is greater than the average cave temperature an air-tight door remains closed, and when the external temperature is lower than the average cave temperature the door is open. An automated door opening and closing regime may be sufficient to passively reduce $\mathrm{Rn}$ in the cave to acceptable levels $\left(<<1,000 \mathrm{~Bq} \mathrm{~m}^{-3}\right)$.

While many caves have some proportion of bi-directional convective ventilation there are other cave configurations, often with only one significant entrance or exit where $\mathrm{Rn}$ ingress is not driven by convective air flow as a result of warmer external temperatures. A passive Rn exclusion strategy is less likely to be successful in reducing $\mathrm{Rn}$ for these cave configurations with one entrance and no convective air flow. Increased convective air flow from opening a door may provide a second entrance or exit and have a complex material impact on $\mathrm{Rn}, \mathrm{Rn}$ progeny, equilibrium factor (Zahorowski et al., 1998). An example from Jenolan Caves system is the Temple of Baal, which has a winter high, summer low Rn pattern (Barnes et al., 2001; Whittlestone et al., 2003) and no correlation with $\mathrm{CO}_{2}$ concentration (Baker, 2014).

\section{Technologies Available to Reduce Cave Rn Concentration}

Simple room air-conditioning demonstrates effective lowering of indoor Rn (Yu et al., 1995), however air-conditioning is not feasible to implement for most caves. Air conditioning and central heating coupled with door opening and closing reduces indoor Rn (Marley and Phillips, 2001) by stimulating indoor air-exchange similar to cave chimney effect ventilation. Both indoor and cave systems show an inverse correlation between indoor-cave Rn and indoor-cave temperature, a corollary to winter pattern air flushing. Mitigation measures that clean cave air with an electrostatic air cleaner (EAC), an ion generator/fan system (IG/F), or a filtration unit (Hopke et al., 1993) may significantly reduce cave Rn progeny by $63 \%, 34 \%$, and $66 \%$, respectively. However, air conditioners and air cleaners may also change cave humidity and significantly detract from the cave visitor experience by addition of background noise.

\section{Cave Rn and Rn Progeny, Relative Humidity}

Cave $\mathrm{Rn}$ activity monitoring is essential to implement management controls for the reduction of Rn exposure to cave workers. Modifying passive cave ventilation to reduce Rn may also affect the size distribution of aerosol particulate (Fig. 1) and equilibrium factor with Rn progeny (Zahorowski et al., 1998), which materially affects received dose of Rn. If the estimated received dose from $\mathrm{Rn}$ in a cave warrants further consideration (may approach dose limits) monitoring cave Rn progeny will provide a more accurate assessment of cave worker received dose, rather than rely on an assumption of a default $\mathrm{Rn}-\mathrm{Rn}$ progeny equilibrium factor. This is an important subtle distinction that may change the cave worker 
received dose estimate by $50 \%$. Direct measurement of Rn progeny is more accurate than estimation of dose from $\mathrm{Rn}$ alone because approximately $90 \%$ of the received dose is from $\mathrm{Rn}$ progeny retention in the lungs.

Modifying cave ventilation patterns to reduce Rn may also impact cave humidity producing either condensation or drying effects. Monitoring relative humidity in caves is necessary to manage and to avoid potential deleterious effects on speleothems.

\section{SUMMARY AND CONCLUSION}

At Jenolan Caves, detailed cave monitoring has measured many parameters including continuous Rn concentration patterns in Chifley Cave to identify the source of the $\mathrm{Rn}$ as the soil above the cave. Bi-directional convective ventilation draws $\mathrm{Rn}$ and $\mathrm{CO}_{2}$ into Chifley Cave when external temperature is greater than cave temperature, typically during summer. Air flow in the opposite direction typically during winter dilutes cave $\mathrm{Rn}$ and $\mathrm{CO}_{2}$ with ambient air. This common seasonal convective ventilation pattern explains the major variation of $\mathrm{Rn}$ in caves with further cave $\mathrm{Rn}$ variation due to a cascade of dependencies from external weather (temperature) driving diurnal variation, site specific soil cover above the cave (Rn source concentration), and climatic zone driving convective air flow through major passages of complex $3 \mathrm{D}$ voids with multiple possible connections to isolated passages. Within a cave, Rn concentration may vary over a few tens of meters due to exposure to different internal micro-ventilation patterns that also extends to time of day and season.

Small inter-annual average surface temperature variability $\left(\sim 0.5^{\circ} \mathrm{C}\right)$ amplifies the net convective air-mass exchange to transport $\sim 60 \%$ more $\mathrm{CO}_{2}$ and implicitly $\mathrm{Rn}$ into Chifley Cave. Decadal average surface temperature increase due to climate change may also significantly increase $\mathrm{CO}_{2}$ and $\mathrm{Rn}$ in caves by diminishing the annual average difference between relatively warm cave air.

The received radiation dose to cave workers exposed to high $\mathrm{Rn}$ in caves has changed significantly since initial surveys of cave Rn in the 1990's, principally because of changes to appreciated health risk by the ICRP and recommended dose conversion factors. As a result, received dose has increased by a factor of 4-6 for a similar Rn concentration. Most caves have an annual average $\mathrm{Rn}$ activity above the ICRP recommended $1,000 \mathrm{~Bq} \mathrm{~m}^{-3}$ reference or action level.

Cave managers face difficult decisions on what actions may mitigate Rn exposure without detriment to workers or cave formations with incomplete monitoring or dosimetry data. Rescheduling of worker hours underground and limiting tours or time in caves with high Rn concentration may achieve regulatory compliance but may not achieve significant reduction of total dose received collectively by all cave workers. Changing natural air flow patterns by closing air-tight doors when external temperature is greater than cave temperature is likely to reduce $\mathrm{Rn}$ being drawn into caves. The converse action of opening air-tight doors when external temperature is cooler than cave temperature is likely to increase the natural convective flushing of $\mathrm{Rn}$ from caves. Changing air flow in caves also carries a perceived risk of potential impact on speleothems through drying or condensation corrosion. Lowering cave $\mathrm{Rn}$ while maintaining cave humidity through passive intervention of natural ventilation patterns, such as opening airtight doors when colder outside the cave and closing when hotter, is a promising mitigation measure that may lower Rn for caves with chimney effect ventilation.

Most show caves will require monitoring to accurately measure the highly dynamic $\mathrm{Rn}$ and $\mathrm{Rn}$ decay product variability in the workplace and demonstrate minimal health risk to cave workers. If cave Rn monitoring shows an estimated potential dose to cave workers in excess of $10 \mathrm{mSv} \mathrm{y}^{-1}$ for radiation exposed workers, mitigation of Rn in show caves needs to be instigated.

\section{ACKNOWLEDGEMENTS}

The authors wish to thank the many Cave Guides and Managers at Jenolan for their interest, curiosity, and assistance during our studies, Grant Commins, Dan Cove, Geoff Melbourne, Michael, Alison, Gordon, Ted, lan, Emma, Anne, Ingrid, and Jodie with apologies for many omissions. The NSW National Parks and Wildlife Service and particularly Sophia Meehan have patiently supported our research, where the outcomes of multi-year, multi-parameter cave monitoring studies are not necessarily initially known. We also acknowledge the role and support of Australian Government agencies Australian Nuclear Science and Technology Organisation and Australian Radiation Protection And Nuclear Safety Authority for funding research for public good. The anonymous reviewers for the Journal of Cave and Karst Studies, Associate Editors and Advisory Board are thanked for their encouragement and constructive criticism.

\section{REFERENCES}

Ahlstrand, G.M., 1980, Alpha radiation levels in two caves related to external air temperature and atmospheric pressure: Bulletin of the National Speleological Society v. 42, p. 39-41.

Atkinson, T.C., Smart, P.L., Wigley, T.M.L., 1983, Climate and Natural Radon Levels in Castleguard Cave, Columbia Icefields, Alberta, Canada: Arctic and Alpine Research, v. 15, no. 4, p. 487-502. https://doi.org/10.2307/1551235

Badino, G., 2010, Underground Meteorology-"What's the weather underground?": Acta Carsologica, v. 39, no. 3, p. 427-448. https://doi. org/10.3986/ac.v39i3.74 
Baker, A.C., 2014, The Jenolan Environmental Monitoring Program: Proceedings of the Linnean Society of New South Wales, v. 136, p. $19-34$.

Barnes, C.M., James, J.M., Whittlestone, S., 2001, Radon Studies in Jenolan Tourist Caves, New South Wales, Australia, in Proceedings 13th International Congress of Speleology, Brasília DF, Brazil, 15 - 22 July 2001, p. 43-48.

Bashor, B., 2004, Big Bone Cave State Natural Area, Van Buren County, Tennessee: U.S. Department of Health and Human Services, Public Health Service, Agency for Toxic Substances and Disease Registry (ATSDR).

Bottrell, S., 1991, Radon Production and Release from Cave Sediments: Cave Science Transactions of the British Cave Research Association, v. 18 , no. 2, p. 79-83.

Burian, I., Stelcl, O., 1990, Radon and its daughters in the touristic caves of the Moravian Karst, in Proceedings International Conference of Anthropogenic Impact and Environmental Changes in Karst, Czechoslovakia, Institute of Geographers, Czechoslovak Academy of Science, p. 27-32.

Cheng, Y.-S., Chen, T.-R., Wasiolek, P.T., Van Engen, A., 2007, Radon and Radon Progeny in the Carlsbad Caverns: Aerosol Science and Technology, v. 26, no. 1, p. 74-92. https://doi.org/10.1080/02786829708965416

Cigna, A.A., 2005, Radon in Caves: International Journal of Speleology, v. 34, no. 1-2, p. 1-18. https://doi.org/10.5038/1827-806X.34.1.1

Covington, M.D., Perne, M., 2016, Consider a cylindrical cave: A physicist's view of cave and karst science: Acta Carsologica, v. 44, no. 3, p. 363-380. https://doi.org/10.3986/ac.v44i3.1925

Dueñas, C., Fernández, M.C., Cañete, S., Carretero, J., Liger, E., 1998, ${ }^{222}$ Rn concentrations, natural flow rate and the radiation exposure levels in the Nerja Cave: Atmospheric Environment, v. 33, no. 3, p. 501-510. https://doi.org/10.1016/S1352-2310(98)00267-2

Duffy, J.T., Madden, J.S., Mackin, G.M., McGarry, A.T., Colgan, P.A., 1996, A reconnaissance survey of radon in show caves in Ireland: Environment International, v. 22, p. 415-423. https://doi.org/10.1016/S0160-4120(96)00140-7

Eheman, C., Carson, B., Rifenburg, J., Hoffman, D., 1991, Occupational exposure to radon daughters in Mammoth Cave National Park: Health Physics, v. 60, no. 6, p. 831-835.

Fairchild, I.J., Baker, A., 2012, Speleothem Science: From Process to Past Environments, Wiley-Blackwell, 432 p. https://doi. org/10.1002/9781444361094

Fernandez-Cortes, A., Cuezva, S., Alvarez-Gallego, M., Garcia-Anton, E., Pla, C., Benavente, D., Jurado, V., Saiz-Jimenez, C., and Sanchez-Moral, S., 2015, Subterranean atmospheres may act as daily methane sinks: Nature Communications, v. 6, p. 7003. https://doi. org/10.1038/ncomms 8003

Field, M.S., 2007, Risks to Cavers and Cave Workers from Exposures to Low-Level lonizing a Radiation From ${ }^{222}$ Rn Decay In Caves: Journal of Cave and Karst Studies, v. 69, no. 1, p. 207-228.

Gamble, F.M., 1981, Alpha radiation in karst caves of the Transvaal, South Africa: Transactions of the British Cave Research Association, v. 8, no. 4, p. 254-260.

Gillmore, G., Gilbertson, D., Grattan, J., Hunt, C., McLaren, S., Pyatt, B., Mani Banda, R., Barker, G., Denman, A., Phillips, P., and Reynolds, T., 2005 , The potential risk from ${ }^{222}$ radon posed to archaeologists and earth scientists: reconnaissance study of radon concentrations, excavations, and archaeological shelters in the Great Cave of Niah, Sarawak, Malaysia: Ecotoxicology and Environmental Safety, v. 60, no. 2, p. 213-227. https://doi.org/10.1016/j.ecoenv.2003.12.014

Gillmore, G.K., Phillips, P.S., Denman, A.R., Gilbertson, D.D., 2002, Radon in the Creswell Crags Permian limestone caves: Journal of Environmental Radioactivity, v. 62, no. 2, p. 165-179. https://doi.org/10.1016/S0265-931X(01)00159-X

Gillmore, G.K., Sperrin, M., Phillips, P., Denman, A., 2000, Radon Hazards, Geology, and exposure of cave users: A case study some theoretical perspectives: Ecotoxicology and Environmental Safety, v. 46, no. 3, p. 279-288. https://doi.org/10.1006/eesa.2000.1922

Greene, C.A., Thirumalai, K., Kearney, K.A., Delgado, J.M., Schwanghart, W., Wolfenbarger, N.S., Thyng, K.M., Gwyther, D.E., Gardner, A.S., Blankenship, D. D., 2019, The Climate Data Toolbox for MATLAB: Geochemistry, Geophysics, Geosystems, v. 20, no. 7, p. 3774-3781. https:// doi.org/10.1029/2019GC008392

Gregorič, A., Vaupotič, J., Gabrovšek, F., 2013, Reasons for large fluctuation of radon and $\mathrm{CO}_{2}$ levels in a dead-end passage of a karst cave (Postojna Cave, Slovenia): Natural Hazards and Earth System Sciences, v. 13, no. 2, p. 287-297. https://doi.org/10.5194/nhess-13-287-2013

Gregorič, A., Vaupotič, J., Šebela, S., 2014, The role of cave ventilation in governing cave air temperature and radon levels (Postojna Cave, Slovenia): International Journal of Climatology, v. 34, no. 5, p. 1488-1500. https://doi.org/10.1002/joc.3778

Gunn, J., 1991, Radon Concentrations in three Russian cave areas: Cave Science Transactions of the British Cave Research Association, v. 18, no. 2, p. 85-89.

Gunn, J., Fletcher, S., Prime, D., 1991, Research on radon in British limestone caves and Mines, 1970-1990: Cave Science Transactions of the British Cave Research Association, v. 18, no. 2, p. 63-67.

Hakl, J., Hunyadi, I., Csige, I., Géczy, G., Lénárt, L., Várhegyi, A., 1997, Radon transport phenomena studied in Karst caves-international experiences on radon levels and exposures: Radiation Measurements, v. 28, no. 1, p. 675-684. https://doi.org/10.1016/S1350-4487(97)00163-7

Hopke, P.K., Montassier, N., Wasiolek, P., 1993, Evaluation of the Effectiveness of Several Air Cleaners for Reducing the Hazard from Indoor Radon Progeny: Aerosol Science and Technology, v. 19, no. 3, p. 268-278. https://doi.org/10.1080/02786829308959635

Hyl, R., Gunn, J., 1994, International comparison of cave radon concentrations identifying the potential alpha radiation risks to British cave users: Health physics, v. 67, no. 2, p. 176-179. https://doi.org/10.1097/00004032-199408000-00009

ICRP, 1987, ICRP Publication 50: Lung Cancer Risk from Exposures to Radon Daughters: Annals of the ICRP, v. 17, no. 1, p. 58. https://doi.org/10.1016/0146-6453(87)90044-3

ICRP, 1991, ICRP Publication 60: 1990 Recommendations of the International Commission on Radiological Protection.: Annals of the ICRP, v. 21, no. 1-3, p. 1-201.

ICRP, 1993, ICRP Publication 65: Protection against Radon-222 at Home and at Work.: International Journal of Radiation Biology, v. 65, no. 4, p. 1-413. https://doi.org/10.1080/09553009414551371

ICRP, 1994, ICRP Publication 66: Human Respiratory Tract Model for Radiological Protection: Annals of the ICRP, v. 24, no. 1-3, p. 1-482. https://doi.org/10.1016/0146-6453(94)90004-3

ICRP, 2007, ICRP Publication 103: Recommendations of the ICRP: Annals of the ICRP, v. 103, p. 1-334.

ICRP, 2010, ICRP Publication 115: Lung Cancer Risk from Radon and Progeny and Statement on Radon: Annals of the ICRP, v. 40, no. 1, p. 1-64. https://doi.org/10.1016/j.icrp.2011.08.011

ICRP, 2014, ICRP Publication 126: Radiological Protection against Radon Exposure: Annals of the ICRP, v. 43, no. 3, p. 5-73. https://doi. org/10.1177/0146645314542212 
Waring, Hankin, Solomon, Long, Yule, Blackley, Werczynski, and Baker

ICRP, 2017, ICRP Publication 137: Occupational Intakes of Radionuclides: Part 3: Annals of the ICRP, v. 46, no. 3-4, p. 1-486. https://doi. org/10.1177/0146645317734963

ICRP, 2019a, Calculating Radon Doses, ICRPædia.

ICRP, 2019b, Radon Recommendations for Workplaces, ICRPædia.

Kobal, I., Ancik, M., Skofljanec, M., 1988, Variations of ${ }^{222}$ Rn air concentration in Postojna Cave: Radiation Protection Dosimetry, v. 25, no. 3, p. 207-211.

Kobal, I., Smodis, B., Burger, J., Skofljanec, M., 1987, Atmospheric ${ }^{222}$ Rn in tourist caves of Slovenia, Yugoslavia: Health physics, v. 52, no. 4, p. 473-479. https://doi.org/10.1097/00004032-198704000-00008

Kowalczk, A.J., Froelich, P.N., 2010, Cave air ventilation and $\mathrm{CO}_{2}$ outgassing by radon-222 modeling: How fast do caves breathe?: Earth Planetary Science Letters, v. 289, no. 1-2, p. 209-219. https://doi.org/10.1016/j.epsl.2009.11.010

Lario, J., Sánchez-Moral, S., Cañaveras, J. C., Cuezva, S., Soler, V., 2005, Radon continuous monitoring in Altamira Cave (northern Spain) to assess user's annual effective dose: Journal of Environmental Radioactivity, v. 80, no. 2, p. 161-174. https://doi.org/10.1016/j.jenvrad.2004.06.007

Lenart, L., Somogyi, G., Hakl, J., Hunyadi, I., Radon mapping in caves of eastern Bukk region, 1990, in Proceedings Proceedings of the 10th International Congress of Speleology, Czechoslovakia, Institute of Geographers, Czechoslovak Academy of Science, p. 21-31.

Luetscher, M., Jeannin, P.-Y., 2004, Temperature distribution in karst systems: the role of air and water fluxes: Terra Nova, v. 16, no. 6, p. 344-350. https://doi.org/10.1111/j.1365-3121.2004.00572.x

Marley, F., Phillips, P.S., 2001, Investigation of the potential for radon mitigation by operation of mechanical systems affecting indoor air: Journal of Environmental Radioactivity, v. 54, no. 2, p. 205-219. https://doi.org/10.1016/S0265-931X(00)00091-6

Middleton, T., Gunn, J., Fletcher, S., Prime, D., 1991, Radon Daughter Concentrations in Giant's Hole, Derbyshire: Cave Science Transactions of the British Cave Research Association, v. 18, no. 2, p. 67-71.

Miki, T., Ikeya, M., 1980, Accumulation of atmospheric radon in calcite caves: Health Physics, v. 39, no. 2, p. 351-354.

Nikezic, D., Yu, K.N., 2001, Alpha hit frequency due to radon decay products in human lung cells: International Journal of Radiation Biology, v. 77, no. 5, p. 559-565. https://doi.org/10.1080/09553000110035233

Papastefanou, C., Manolopoulou, M., Savvides, E., Charalambous, S., 1986, Natural radiation dose in Petralona Cave: Health physics, v. 50 , no. 2, p. 281-286.

Pla, C., Galiana-Merino, J.J., Cuezva, S., Fernandez-Cortes, A., Cañaveras, J.C., Benavente, D., 2016, Assessment of $\mathrm{CO}_{2}$ dynamics in subsurface atmospheres using the wavelet approach: from cavity-atmosphere exchange to anthropogenic impacts in Rull cave (Vall d'Ebo, Spain): Environmental Earth Sciences, v. 75, no. 446, p. 1-16. https://doi.org/10.1007/s12665-016-5325-y

Przylibski, T.A., 1999, Radon concentration changes in the air of two caves in Poland: Journal of Environmental Radioactivity, v. 45, no. 1, p. 81-94. https://doi.org/10.1016/S0265-931X(98)00081-2

Sainz, C., Rábago, D., Celaya, S., Fernández, E., Quindós, J., Quindós, L., Fernández, A., Fuente, I., Arteche, J.L., Quindós, L.S., 2018, Continuous monitoring of radon gas as a tool to understand air dynamics in the cave of Altamira (Cantabria, Spain): Science of The Total Environment, v. 624, p. 416-423. https://doi.org/10.1016/j.scitotenv.2017.12.146

Solomon, S.B., 2019, Reassessment of inhalation doses to workers in Australian show caves: Radiation Protection Dosimetry, v. 184, no. 3-4, p. 298-301. https://doi.org/10.1093/rpd/ncz099

Solomon, S.B., Langroo, R., Lyons, R.G., James, J.M., 1996, Radon exposure to tour guides in Australian show caves: Environment International, v. 22, p. 409-413. https://doi.org/10.1016/S0160-4120(96)00139-0

Somogyi, G., Hunyadi, I., Hakl, J., 1989, Historical review of one decade of radon measurements in Hungarian caves performed by solid state nuclear track detection technique, Proceedings of the 10th International Congress of Speleology, Erscheinung Publishers, p. 3-13.

Surbeck, H., 1990, Radon-222 transport from soil to karst caves by percolation water, In Proceedings of the 22nd Congress of the IAH, International Association of Hydrogeologists, International Association of Hydrogeologists, p. 349-355.

Surbeck, H., 2005, Dissolved gases as natural tracers in karst hydrogeology: Radon and beyond, In Proceedings of Multidisciplinary Approach to Karstwater Protection Strategy, Budapest, Hungary, UNESCO.

Szerbin, P., 1996, Radon concentrations and exposure levels in Hungarian caves: Health physics, v. 71, no. 3, p. 362-369. https://doi. org/10.1097/00004032-199609000-00014

Tanahara, A., Taira, H., Takemura, M., 1997, Radon distribution and the ventilation of a limestone cave on Okinawa: Geochemical Journal, v. 31, p. 49-56. https://doi.org/10.2343/geochemj.31.49

Tate, B., Long, S., 2016, Acceptance Testing of the TASL Radon Dosimetry System: ARPANSA TR 175.

Tremaine, D.M., Froelich, P.N., Wang, Y., 2011, Speleothem calcite farmed in situ: Modern calibration of $\delta^{18} \mathrm{O}$ and $\delta^{13} \mathrm{C}$ paleoclimate proxies in a continuously-monitored natural cave system: Geochimica et Cosmochimica Acta, v. 75, no. 17, p. 4929-4950. https://doi.org/10.1016/j. gca.2011.06.005

UNSCEAR, 1982, Ionizing radiation: sources and biological effects 1982 report to the General Assembly, with annexes, United States, United Nations.

UNSCEAR, 2000, Sources and effects of ionizing radiation - Annex B:, Vienna, Austria, United Nations Scientific Committee on the Effects of Atomic Radiation, Exposures from natural radiation sources, $156 \mathrm{p}$.

UNSCEAR, 2009, Annex, E. Sources-to-effects assessment for radon in homes and workplaces: UNSCEAR 2006 Report, p. 197-334.

Wang, Y., Luo, W., Zeng, G., Wang, Y., Yang, H., Wang, M., Zhang, L., Cai, X., Chen, J., Cheng, A., Wang, S., 2019, High 222Rn concentrations and dynamics in Shawan Cave, southwest China: Journal of Environmental Radioactivity, v. 199-200, p. 16-24. https://doi.org/10.1016/j. jenvrad.2018.12.029

Waring, C.L., Hankin, S.I., Griffith, D.W.T., Kertesz, M.A., Kobylski, V., Wilson, N.L., Coleman, N.V., Kettlewell, G., Zlot, R., Bosse, M., Bell, G., 2017, Seasonal total methane depletion in limestone caves: Scientific Reports, v. 7, no. 1, p. 8314. https://doi.org/10.1038/s41598-017-077696

Whittlestone, S., James, J., Barnes, C., 2003, The relationship between local climate and radon concentration in the Temple of Baal, Jenolan Caves, Australia: Helictite, v. 38, no. 2, p. 39-44.

Wiegand, J., Feige, S., Quingling, X., Schreiber, U., Wieditz, K., Wittmann, C., Xiarong, L., 2000, Radon and Thoron in Cave dwellings (Yan'an, China): Health Physics, v. 78, no. 4, p. 438-444. https://doi.org/10.1097/00004032-200004000-00008

Wigley, T.M.L., Brown, M.C., 1971, Geophysical applications of heat and mass transfer in turbulent pipe flow: Boundary-Layer Meteorology, v. 1, no. 3, p. 300-320. https://doi.org/10.1007/BF02186034 
Wigley, T.M.L., Brown, M.C., 1976, The Physics of Caves, New York, Academic Press, The Science of Speleology.

Yarborough, K.A., 1976, Investigation of radiation produced by radon and thoron in natural caves administered by National Park Service: First Conference on Scientific Research in the National Parks, in Proceedings National. Park Service Trans. Proc. Ser.1979, v. 5, p. 703-713.

Yu, K.N., Guan, Z.J., Liu, X.W., Young, E.C.M., Stokes, M.J., Cheung, T., 1995, Mitigation of indoor radon hazard by air conditioning: Journal of Radiological Protection, v. 15, no. 1, p. 67-71. https://doi.org/10.1088/0952-4746/15/1/005

Zahorowski, W., Whittlestone, S., James, J.M., 1998, Continuous measurements of radon and radon progeny as a basis for management of radon as a hazard in a tourist cave: Journal of Radioanalytical and Nuclear Chemistry, v. 236, no. 1-2, p. 219-225. https://doi.org/10.1007/BF02386346

Zlot, R., Bosse, M., 2014, Three-dimensional mobile mapping of caves: Journal of Cave Karst Studies, v. 76, no. 3, p. 191-206. https://doi. org/10.4311/2012EX0287

Zlot,R., Bosse, M., 2015, Jenolan Caves: 3D Data Collection, v. 1, CSIRO. Data Collection. 